Acta Theriologica 41 (1): 1-34, 1996.

PL ISSN 0001-7051

\title{
Rodent cycles in relation to biomass and productivity of ground vegetation and predation in the Palearctic
}

\author{
Włodzimierz JEDDRZEJEWSKI and Bogumiła JĘDRZEJEWSKA
}

Jędrzejewski W and Jędrzejewska B. 1996. Rodent cycles in relation to biomass and productivity of ground vegetation and predation in the Palearctic. Acta Theriologica 41: 1-34.

We have synthesized the data on population dynamics and densities of rodents in seven biomes of the Palearctic (mainly western part), and related them to the data on standing crop of biomass and net productivity of ground vegetation (as rough indicators of food availability to rodents). Analysis of 44 long-term ( $\geq 5$ years) series of rodent trapping showed that there was a continuum from highly cyclic to non-cyclic populations. Rodents inhabiting tundra, taiga, steppe, and farmlands (wintercrops) in the temperate zone have highest cyclicity indices. Definitely non-cyclic are rodents in the temperate forests (mixed and deciduous forests, steppe woodland) and desert.

Standing crop of biomass of ground vegetation (analysis of 63 data points) correlated positively with latitude; it was highest in the northern tundra and decreased towards South. Variation within biomes was most pronounced in the temperate zone, with forests having ground vegetation biomass as low as that in deserts, whereas farmlands in that zone - as high as that in tundra. In various habitats (natural open, farmland, and forested) located in seven biomes, the mean index of rodent cyclicity was significantly positively correlated to the mean standing crop of ground vegetation.

Net productivity of ground vegetation (30 data points) did not show latitudinal trends. It was lowest in desert, tundra, and all types of forests, and highest in open habitats of the temperate zone and steppes. Mean densities of rodents (calculated as averaged spring and autumn estimates) were lowest in tundra, desert, and all types of forests ( $8-29$ rodents/ha). The highest average densities were recorded in the farmlands of temperate zone and steppe (143-490 rodents/ha). Mean and maximum densities of rodents were strongly positively correlated with the mean productivity of ground vegetation.

Dichotomy between seasonal (non-cyclic) and multiannual (cyclic) fluctuations in rodent numbers was not found. The magnitude of seasonal changes in rodent densities (from spring to autumn) was a continuous variable related to the propitiousness of climate for plant growth. Irrespectively of the type of population dynamics, seasonal changes in rodent densities were small in the coolest and the hottest biomes (tundra, desert) and big in the temperate zone.

Results of our long-term study on predation on rodents in the temperate deciduous forests did not support the hypothesis on the role of specialist and generalist predators in shaping rodent dynamics. We found no qualitative difference between predatory impacts by generalist and specialist predators. All predators exerted the heaviest impact at low or moderate densities of rodents (inversely density-dependent predation). Predation may be an important factor of rodent mortality but it does not shape the pattern of rodent population dynamics.

Based on the observed vegetation-rodent correlations, we have proposed an interpretation of the mechanisms of rodent population dynamics in the Palearctic biomes A prerequisite for rodent cycles to occur is abundant winter food, which enables rodents to continue an increase phase beyond one growing season (by winter breeding). Habitats with mean standing crop of ground vegetation of over $4000 \mathrm{~kg}$ dry weight/ha in summer are expected to harbour cyclic populations of rodents. 
Mammal Research Institute, Polish Academy of Sciences, 17-230 Białowieza, Poland (WJ); Workshop for Ecology and Protection of the Natural Environment, 17-230 Bialowieza, Poland (BJ)

Key words; rodent cycles, ground vegetation biomass, productivity, generalist predators, specialist predators, predation, regulation

\section{Contents}

$\begin{array}{lr}\text { Introduction } & 2 \\ \text { Material and methods } & 4 \\ \text { Analysis of literature data on rodent dynamics and abundance of ground vegetation } & 5 \\ \quad \text { Palearctic viewpoint on rodent dynamics } & 5 \\ \quad \text { Rodent cyclicity and biomass of ground vegetation } & 7 \\ \quad \text { Rodent densities and plant productivity } & 11 \\ \text { Role of predation in shaping rodent dynamics - hypotheses and results of empirical studies } & 13 \\ \text { Discussion - interpretation of observed vegetation-rodents correlations as cause-effect relationships } & 17 \\ \text { References } & 22 \\ \text { Appendix I } & 29 \\ \text { Appendix II } & 31 \\ \text { Appendix III } & 33\end{array}$

\section{Introduction}

In the $1920 \mathrm{~s}, \mathrm{C}$. Elton made a research trip to the European North and described 3-4-year cycles of lemmings and voles with a striking aspect of long distance migrations of lemmings in some peak years (Elton 1924, 1942). Later generations of scientists pursuing the explanation of cycles collected great amount of data and offerred several hypotheses, which emphasized either intrinsic regulation (physiological stress, Christian 1950; genetic polymorphism, Chitty 1960) or extrinsic regulation (plant productivity and chemical composition, Kalela 1962, Haukioja 1980, Laine and Henttonen 1983; predation, Hansson 1987). So far, however, no consensus has been achieved as to where and why rodents cycle (Pitelka and Schultz 1964, Krebs and Myers 1974, Hansson and Henttonen 1985, Lidicker 1988, Hanski et al. 1991, Batzli 1992).

In the 1920s, too, an expedition of Russian scientists (A. N. Formozov, K. A. Kazanskiï and others) to Mongolian steppes found spectacular cycles of Microtus brandt $i$ with a striking aspect of their long distance migrations in some peak years (Kazanskii 1930). Numerous large scale programs that followed yielded a wealth of information but, usually, a specific set of abiotic and biotic conditions (with a strong emphasis on disease) was proposed as explanation for the observed phenomena (Naumov 1948, Kalabukhov 1949, Semenov-Tyan-Shanskiï 1970, Dombrovsky 1971, Chernyavskiï and Dorogoï 1981).

In the 1960s and 1970s, some studies of the International Biological Programme aimed at analysis of productivity of plants and cyclic or non-cyclic rodent popu- 
lations feeding on them (Hansson 1971a, Ryszkowski et al. 1973, Aulak 1973, Babinska-Werka 1979). Surprisingly, they contributed little to our understanding why rodent populations cycle. Oversimplified formulas from ecology textbooks (Krebs 1972, Begon et al. 1986) showing the latitudinal gradients in biomass and productivity of terrestrial vegetation, have led to a tenet that, also for small rodents, 'resources generally diminish northwards' (Hansson and Henttonen 1985), 'if there is any geographic trend in [carrying capacity of rodents], it decreases with increasing latitude' (Hanski et al. 1991). Yet what is true for the whole vegetation, need not be true for all its layers alike. Arvicoline rodents are small terrestrial animals, to which only the abundance of ground vegetation (ie the whole vegetation in grasslands, but only forest floor vegetation in woodlands) is important. So far, the pattern of latitudinal variation in biomass or productivity of ground vegetation is unknown.

Moreover, the biomass and productivity concepts are often erroneously used interchangeably. Ecology textbooks have emphasized the difference between these two, but both the explanations of the differences (productivity to biomass relation is like 'the interest rate on the capital', Begon et al. 1986) and the large scale correlations between biomass and productivity in the world's biomes can be misleading. In this paper, we use 'biomass' to refer to the standing crop of vegetation at any time, and 'net productivity' to mean the amount of new biomass produced during the course of a growing season.

The observed decline in cyclicity of microtine rodents in the N-S gradient in Fennoscandia (Hansson and Henttonen 1985) seems to be irreconcilable with the presumed increase of food resources from North to South. Instead, a predator regulation hypothesis has been proposed (Hansson 1987, Hanski et al. 1991). It states that specialist predators (mainly small mustelids), which dominate predator community in the North, contribute to rodent cycles, because they continue to hunt the few remaining rodents after the decline and have time lag in numerical response to changes in rodent numbers. Generalist predators, which are more numerous at southern latitudes, switch to alternative prey when rodents are scarse (an S-shaped functional response, Murdoch and Oaten 1975), and thus stabilize rodert dynamics. However, a change in predators cannot account for the fact that still further South (in Central and Southern Europe) cycles of arvicoline rodents still occur and may be the rule rather than exception (Mackin-Rogalska and Nabasło 1990).

In this paper, we synthesized some of the data on rodent dynamics in the main biomes of the Palearctic (particularly its western region; we sought data for eastern Palearctic in the cases of steppes and deserts) and related them to the data on standing crop of biomass and net productivity of ground vegetation (as rough indicators of food availability to rodents). Also, we analysed how the results of our long-ierm study on predation on rodents in the temperate deciduous forests pertaned to the hypothesis on the role of specialist and generalist predators in shaping rodent dynamics. 


\section{Material and methods}

For the analysis of vegetation patterns in the Palearctic, we focused on the following biomes: tundra, taiga (boreal forests), mixed temperate forests (here we classified both mixed coniferous-deciduous forests located in the transitional zone between boreal and nemoral forests, and coniferous forests located in the zone of temperate deciduous forests), steppe woodland, steppe, and desert. We considered only lowland vegetation. Higher altitude tundra was included only if located in the North (Northern Ural, Russia, and Hardangervidda, Norway).

In each biome, we sought for data on up to three types of habitats (i) forests, (ii) natural (and seminatural) open habitats, such as tundra, steppe, as well as marshes and unmown meadows in the zones of boreal and temperate forests, (iii) farmlands with cultivated wintercrops (eg alfalfa, rape, seed grasses). For all types of habitats, we looked for data on the standing crop of biomass of ground vegetation in summer, and net productivity of ground vegetation, collected generally by the methodology of International Biological Programme although with some modifications and adjustments to local conditions (eg Traczyk 1967, Gorchakovskiت̈ and Korobeinikova 1975, Kjelvik and Karenlampi 1975). As 'ground vegetation' we understand the layer of plants potentially available to terrestrial rodents, ie the entire vegetation in tundra, scrub tundra, steppes, meadows, open sedge marshes, and low deserts. In the forests and tall scrub deserts, we considered the forest floor vegetation with dwarf shrubs (eg Ericaceae) and seedlings of trees and shrubs included. In all cases, only the above-ground phytomass was considered. Data on vegetation are listed in Appendix $\mathrm{I}$.

For the analysis of rodent populations, we selected long-term studies $(N=44)$ on the entire local community of rodents, designed to obtain density estimate ( $\mathrm{N}$ inds/ha) or abundance index ( $\mathrm{N}$ inds/100 trapnight) by trapping conducted in a well described habitat (undisturbed tundra and desert, forests, natural unmown grasslands and sedge marshes, wintercrops in farmlands). Series based on number of burrow openings per hectare (numerous in Microtus arvalis and $M$. socialis studies) and on percent of occupied colonies (in studies on steppe and desert rodents) were not used because the first measure overestimated and the latter one underestimated the amplitude of rodent fluctuations.

Cyclicity index (after Hansson and Henttonen 1985) is a standard deviation of the $\log _{10}$ of population size in autumn (the lowest values used were 0.1 ). This index reflects the amplitude of fluctuations but not their regularity or period length. Moreover, it yields higher values if minimum estimates of rodent numbers are $<1$ than in fluctuations with the same amplitude, if the minimum measure of rodent abundance is $>1$. In other words, cycles at lower densities of rodents will have higher cyclicity indices than cycles of the same amplitude at higher densities. Despite these shortcomings, we chose this index to make our analysis comparable to the earlier studies (eg Hansson and Henttonen 1985, Mackin-Rogalska and Nabagło 1990). We calculated cyclicity indices for all trapping series covering at least 5 autumn seasons. Data on rodent dynamics used for the analysis are listed in Appendix II.

We calculated the mean levels of rodent densities in various habitats of Palearctic biomes in the trapping series that had been conducted twice yearly (in spring and autumn) and designed to estimate the number of rodents per unit area. Data and sources are listed in Appendix III. We emphasize that, for the analysis of both fluctuation patterns and densities of rodents, we considered only studies that surveyed the whole community of small rodents. In some habitats, the 'community' was composed of one species (eg Microtus arualis in farmlands).

Data on vegetation and those on rodents come largely from different locations and years. In six cases only, were vegetation and rodents surveyed in the same locality, and in three of them vegetation and rodent surveys overlapped in time (Appendices I-III). Thus, in correlating vegetation parameters with measures of rodent cyclicity and density, we were not able to plot all data points of one variable against those of the other. Instead, we calculated mean estimates of biomass and productivity of ground vegetation in all habitats, and related them to the mean values of rodent cyclicity index and density. It must be kept in mind that regression analysis done on mean values probably shows highe: 
values of $R^{2}$ than would have shown if all inter-habitat variation of both variables could had been included.

The role of predation in shaping rodent population dynamics is discussed in the light of the hypothesis by Hansson (1987), developed further by Hansson and Henttonen (1988) and Hanski $e t$ al. (1991). We analysed, how the results of our 7-year studies on predation on rodents in the temperate deciduous forests (Białowieża National Park, E Poland) pertained to the assumptions and predictions of this hypothesis, particularly to its part regarding the stabilisation of rodent dynamics by generalist predators at southern latitudes in Europe.

\section{Analysis of literature data on rodent dynamics and abundance of ground vegetation}

Palearctic viewpoint on rodent dynamics

The great variability in rodent dynamics can be organized in two gradients: from tundra in the North to desert in the South, and from woodlands to natural open areas (grasslands and marshes) to farmlands (wintercrops) (Fig. 1). The tundra communities of rodents are dominated by lemmings and voles in the genus Microtus which, in taiga and mixed forests, give way to voles in the genus Clethrionomys. In deciduous forests and steppe woodlands, C. glareolus and mice in the genus Apodemus predominate. In this N-S gradient from tundra to temperate forests, the shift from 3-4-year cycles to non-cyclic seasonal fluctuations was described by Hansson and Henttonen (1985). Recently, a specific pattern of population dynamics was described for rodents inhabiting European deciduous forests with the oak Quercus robur (Pucek et al. 1993): 4-7 years of moderate densities and non-cyclic dynamics and 2 years of cycle-like outbreak and crash triggered by heavy crop of tree seeds (marked by arrows in Fig. 1). Since mast years of oak (stimulated by temperature patterns) occur synchronously from Moscow to Oxford, this 'recurrent wave' dynamics of rodents is synchronised wherever oldgrowth oak forests persist (Pucek et al. 1993). In mixed coniferous forests and young plantations, the seasonal fluctuations of rodents prevail (Fig. 1).

When we follow N-S gradient along natural open areas, from tundra to grasslands in the boreal and nemoral zones (mainly river flooded marshes, but also unmown meadows and fallow land in early stages of secondary succession), to steppes and deserts, the 3-4-year cycles of rodents (dominated by various Microtus species) occur everywhere except for the desert, where communities of rodents dominated by Rhombomys and Meriones gerbils usually do not cycle. A spectacular rise of the maximum densities of rodents is seen from tundra to the grasslands in the temperate zone. Still farther South, in dry steppes and deserts, densities fall again to the level lower than that in tundra (Fig. 1). The same pattern of population dynamics and density changes is clear in the N-S gradient of wintercrop fields (Fig. 1).

It is noteworthy, that different dynamics types often occur in one locality. For instance, in Białowieża Forest (E Poland), forest rodents (Clethrionomys glareolus 


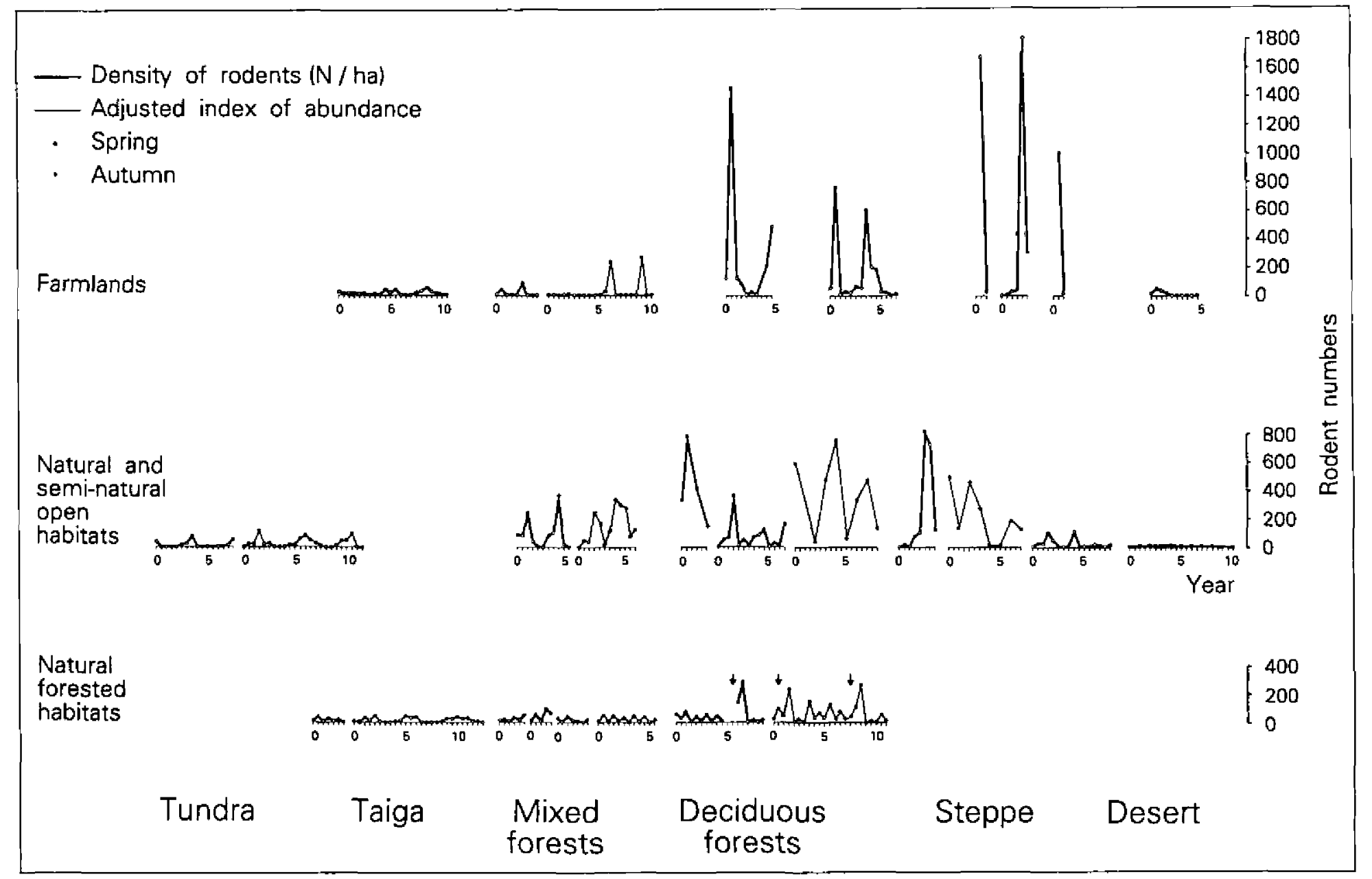


and Apodemus flavicollis) exhibit 'recurrent wave' dynamics, dominated by seasonal fluctuations, whereas Microtus voles in the sedge marshes by the forest undergo 3-4-year cycles (Fig. 1). Similarly, in Revinge (S Sweden), Microtus agrestis in unmown meadows is weakly cyclic (Sandell et al. 1991), whereas $M$. agrestis and Apodemus syluaticus in woodlots and forest plantations interspersed with open grassland show seasonal fluctuations (Hansson 1971a, Erlinge et al. 1983).

\section{Rodent cyclicity and biomass of ground vegetation}

In the Palearctic biomes, the index of rodent cyclicity is related to the standing crop (biomass) of ground vegetation. In tundra and taiga, perennial dwarf shrubs (Ericaceae, Empetraceae, Salicaceae), mosses and lichens (supplemented by monocotyledons and forbs) dominate plant cover, and make the standing crop of vegetation very high (Fig. 2A). Towards South, natural open areas become dominated with monocotyledons (Gramineae, Cyperaceae) and tall forbs, and summer standing crop of biomass is also very high. In contrary, in the temperate deciduous and mixed woodlands, where forest floor is dark in summer, ground vegetation (limited by sunlight) is dominated by spring ephemerals and forbs. As a result, the biomass of forest floor plants in deciduous and mixed forests is as low as that in the desert (Fig. 2A). The highest biomass is recorded in farmlands (data for the temperate zone only were available).

Standing crop of biomass of ground vegetation (a total of 63 data points) correlated positively with latitude (Spearman $r_{\mathrm{S}}=0.51, p<0.01$ ). This means that, generally, the biomass of ground vegetation decreases from North to South. There is, however, a great variation within biomes, particularly between open and forested habitats in the temperate zone. In the entire sample of data, differences

$\leftarrow$ Fig. 1. Rodent dynamics patterns in the main biomes of the Palearctic. Thick lines - densities of rodents (N/ha); thin lines - relative abundance expressed as $\mathrm{N}$ individuals captured per 100 trapnights (in such cases, the level of abundance was arbitrarily adjusted to the densities from other series in the same type of vegetation). Each graph shows combined numbers (or indices of numbers) of all main species of rodents, which constituted majority of all rodents occuring in a given locality. In the case of very long series, the most typical 10-year fragment is shown. Main rodent species and sources of data are as follows (listed in the same order as the dynamics drawn in the graph from the left to the right): tundra - Lien et al. (1975), Laine and Henttonen (1983); taiga - Henttonen et al. (1987); farmland in the zone of taiga - Korpimäki and Norrdahl (1991a, b); mixed forests (forests in the transition between taiga and deciduous forests as well as natural and planted coniferous and mixed forests in the zone of temperate deciduous woodlands) - Smirin (1964), Hansson (1971a), Goszczyński (1977), Zablotskaya (1971); natural and seminatural grasslands in the zone of mixed forests - Myllymäki (1977), Shilov ef al. (1977); farmlands in the zone of mixed forests - Karaseva (1960), Dombrovsky (1971); deciduous forests (arrows denote heavy crops of tree seeds) - Jędrzejewski and Jędrzejewska (1993), Jędrzejewski et al. (1992), Pucek et al. (1993); natural and serninatural grasslands in the zone of deciduous forests - Buchalczyk et al. (1970), Butet and Leroux (1993), Jędrzejewski et al. (1994); farmlands in the zone of deciduous forests (including steppe woodland zone) - Truszkowski (1982), Muntyanu and Sitnik (1994); steppe - Kucheruk and Dunaeva (1948), Tarasov (1983), Petrov and Rozhkov (1963); farmlands in the zone of steppe - Kadochnikov (1953), Gladkina (1968); desert - Dubyanskiï and Dubyanskaya (1980); farmlands in the zone of (semi)desert Rapoport and Semenova (1962). See Appendices II and III for details. 

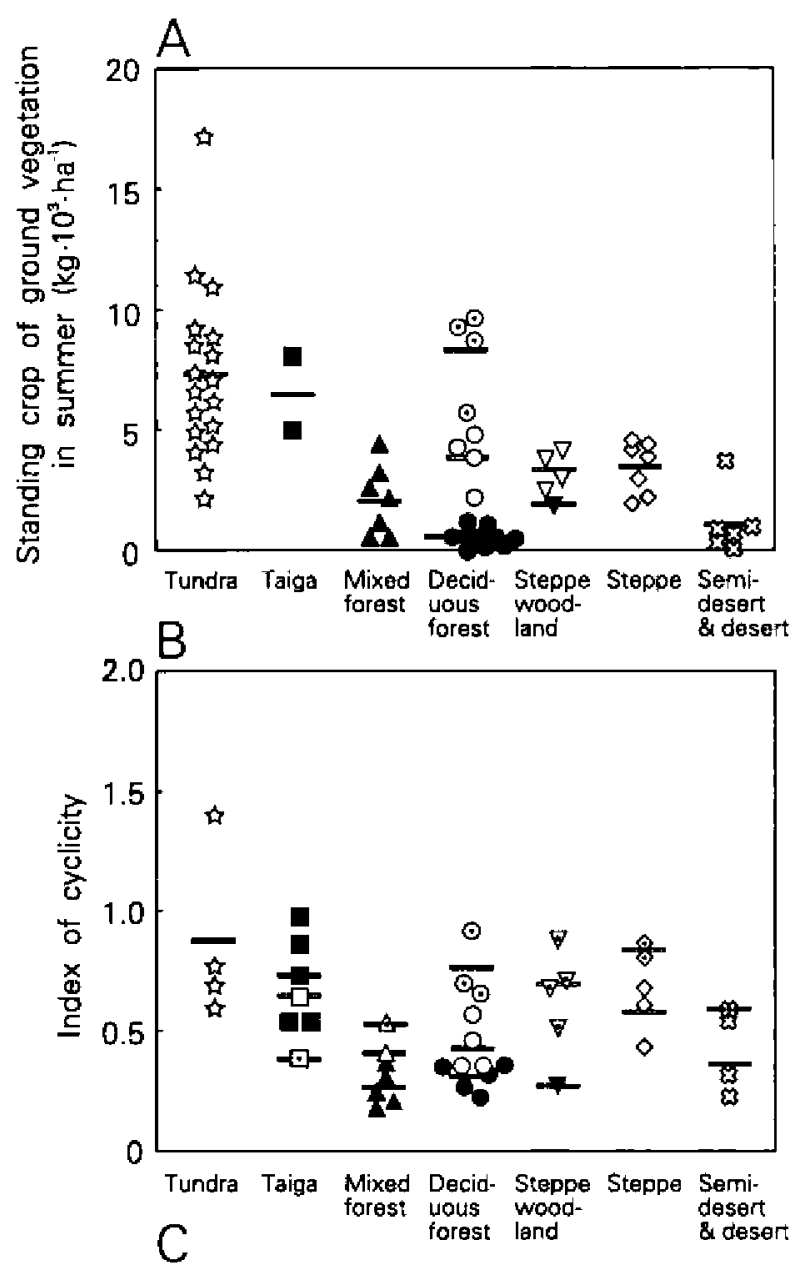

Fig. 2. Relationship between standing crop of biomass of ground vegetation and rodent cyclicity index.

(A) Standing crop of alive ground vegetation (in tons of dry weight of the above-ground phytomass per hectare in summer) in seven main biomes. Each point is one study plot. Shapes of symbols are specific for each biome. Open symbols natural and seminatural open areas; open symbols with dots - farmlands; filled symbols - forests. Horizontal bars are averaged values for all points in a given habitat type. Ground vegetation means the whole vegetation in low and dwarf shrub tundra, grasslands, deserts and farmlands, and the floor vegetation (ie all soft tissue plants, dwarf shrubs and tree seedlings, but no trees or tall shrubs included) in the forests and tall scrub desert. Sources of data are listed in Appendix I.

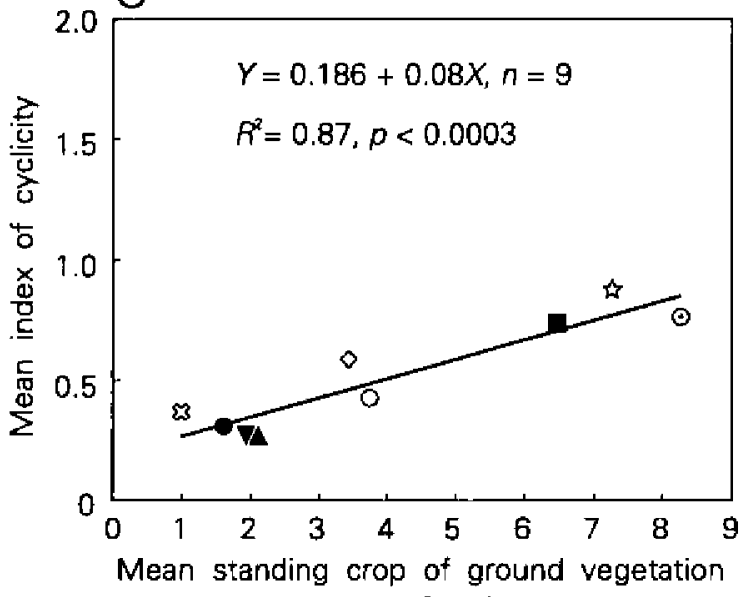

(B) Cyclicity indices of rodents in various vegetation types in seven biomes of the Palearctic. Cyclicity index (after Hansson and Henttonen 1985) was calculated for the studies $\geq 5$ years showing density (N/ha) or number of rodents/100 trapnights. Sources of data and species of rodents trapped are listed in Appendix 11. (C) Relationship between mean index of cyclicity (graph B) and the mean standing crop of biomass of the ground vegetation (graph A) in the Palearctic biomes. In deciduous forests, average crop of tree seeds (1.1 tons/ha), an important food to rodents, was added to the mean standing $\left(\mathrm{kg} \cdot 10^{3} \cdot \mathrm{ha}^{4}\right)$ crop of ground vegetation (see Appendix I). 
between 10 vegetation types accounted for $65 \%$ of total variation in standing crop of ground vegetation (one-way ANOVA, $F=10.938$, $\mathrm{df}=9, p<0.0005$ ). In pairwise comparisons of ground vegetation biomass, tundra differed significantly from mixed and deciduous forests, steppe and desert ( $p$ from $<0.0005$ to 0.009 ), taiga from deciduous forests $(p=0.03)$, and farmlands in the zone of deciduous forests from mixed forests, deciduous forests, steppe, and desert ( $p$ from $<0.0005$ to 0.03 ).

The index of cyclicity was calculated for 44 series of rodent trapping that were conducted in well defined habitats, to which we could assign plant biomass and productivity characteristics. According to Hansson and Henttonen (1985), index value $>0.5$ categorises the population as cyclic, and $<0.5$ as non-cyclic. If we accept this schematic division, rodents in tundra, taiga, grasslands in the zone of taiga, in steppes, and in farmlands in the zones of temperate forests, steppes and deserts are cyclic. Definitely non-cyclic are rodent communities in the mixed and deciduous forests, steppe woodlands and deserts (Fig. 2B).

Differences between 16 vegetation types accounted for $71 \%$ of the total variation in cyclicity indices (one-way ANOVA, $F=4.551$, $\mathrm{df}=15, p<0.0005$ ). In pairwise comparisons, cyclicity indices of rodents in tundra differed significantly from those in mixed forests, deciduous forests, and deserts ( $p$ from 0.001 to 0.03 ), taiga forests from mixed and deciduous forests $(p=0.01$ and 0.04$)$, farmlands in the zone of deciduous forests from mixed forests $(p=0.025)$, and mixed forests from the farmlands in the zones of steppe woodlands and steppes $(p=0.048$ and 0.025$)$.

For rodents in nine vegetation types located in seven biomes, the mean index of cyclicity was significantly related to the mean standing crop of ground vegetation (Fig. 2C). This suggests a cause-effect relationship: high standing crop of biomass means abundant food for rodents. Rodents do not appear to cycle in ecosystems where they have insufficient food resources in winter (see the last section). From the regression shown in Fig. $2 \mathrm{C}$, it can be predicted that habitats with mean standing crop of ground vegetation of over $4000 \mathrm{~kg}$ dry weight/ha in summer harbour cyclic populations of rodents.

Cyclicity indices did not correlate with latitude (Spearman $r_{\mathrm{s}}=0.13, p=0.3$, $n=44$ ). If only latitudes $\geq 55^{\circ} \mathrm{N}$ and all types of vegetation are considered, a significant correlation was detected $\left(r_{\mathrm{B}}=0.51, p<0.05, n=22\right)$, which conforms to the earlier findings (Hansson and Henttonen 1985). However, if one type of habitat (grassland) in the whole spectrum of latitudes was analysed, no significant correlation between cyclicity index and latitude was found $\left(r_{\mathrm{s}}=-0.19, n=9, p=\right.$ $0.7)$. Cyclicity indices were not related to productivity of ground vegetation (calculated on mean values for 8 habitats with data available; $R^{2}=0.15, p=0.3$ )

Summer decline is a consistent feature of cyclic northern populations (Hansson and Henttonen 1985). However, the incidence of decline during summer seasons within the decline phase of cyclic populations is higher at southern latitudes. It was $50 \%$ in tundra, $52 \%$ in taiga forests, $70 \%$ in open habitats in the zone of taiga (grasslands and farmlands combined), $75 \%$ in open habitats in the zone of mixed forests, $63 \%$ in open habitats in the zone of deciduous forests, and $86 \%$ in steppes 

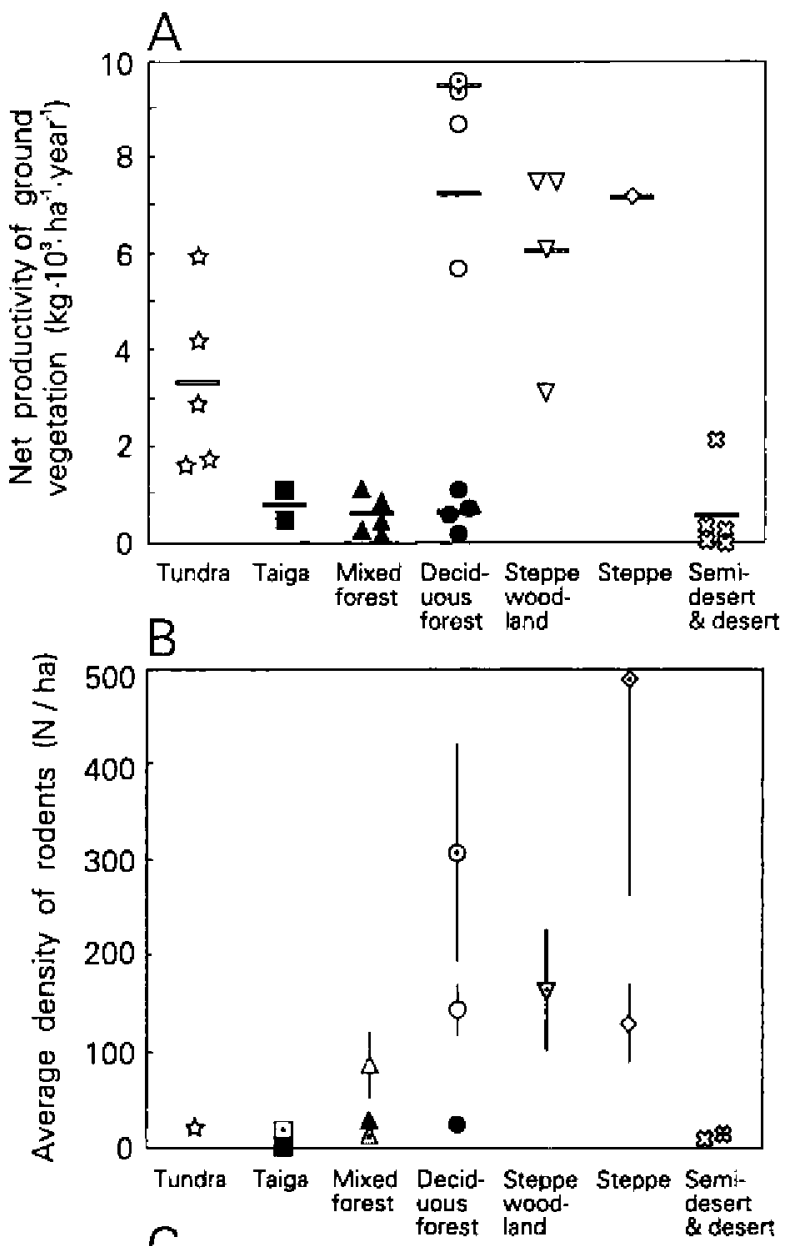

Fig. 3. Relationship between plant productivity and rodent density in the Palearctic biomes.

(A) Net productivity of ground vegetation (in tons of dry weight of biomass per hectare per year) in seven main biomes. Each point is one study plot. Symbols and definition of ground vegetation as in Fig. 2, Sources of data are listed in Appendix I.

(B) Mean ( \pm SE) densities of rodents in the major types of habitats of the Palearctic biomes, calculated for all spring and autumn data points. Only studies on the whole community of rodents or one heavily dominating species were considered. Sources of data and species of rodents are listed in Appendix III. (C) Relationship between mean productivity of ground vegetation (graph A) and mean density of rodents (graph $B$ ) in the main types of habitats in the Palearctic biomes. In the case of deciduous forests, the average crop of tree seeds (as in Fig. 2) was included. vegetation $\left(\mathrm{kg} \cdot 10^{3} \cdot \mathrm{ha}^{-1} \cdot\right.$ year $\left.{ }^{-1}\right)$ 
(natural and cultivated areas combined) (sources: all series with spring and autumn data points listed in Appendix II, and Microtus arvalis from Wałbrzych, Wroclaw, and Szczecin regions in Poland; Romankow-Żmudowska and Grala 1994).

Rodent densities and plant productivity

Productivity in terrestrial ecosystems is shaped by temperature, precipitation and sunlight (Lieth 1975) but it does not grow in the N-S gradient in all types and layers of vegetation alike. In woodlands, especially in deciduous and mixed ones which as a whole are very productive ecosystems ( $O^{\prime} N$ Neill and DeAngelis 1981), the amount of sunlight reaching forest floor is so small that productivity of ground vegetation is low and comparable to that in the deserts (Fig. 3A). In the biomes of Palearctic, productivity of ground vegetation is lowest in desert and boreal and nemoral forests. In deciduous woodlands, tree seeds (mainly oak, hornbeam and beech) add from 0 to 5 tons/ha of high quality food to rodents (Falińska 1971, Mezhzherin and Mikhalevich 1983). Ground vegetation productivity is somewhat higher in tundra, and very high in natural grasslands of the temperate zone (Fig. 3A). Farmlands (wintercrops) have the highest productivity among the Palearctic terrestrial ecosystems. No information on crops in steppes, desert, and boreal zone was found.

In the whole sample of 30 data points, productivity of ground vegetation was not related to the latitude $\left(r_{\mathrm{S}}=0.23, p>0.05\right)$. Differences between the nine vegetation types accounted for $88 \%$ of the total variation in productivity (one-way ANOVA, $F=20.061$, $\mathrm{df}=8, p<0.0005$ ). Significant differences in pairwise comparisons were between all types of forests and all open areas (both natural and cultivated) in the temperate and steppe zones ( $p$ from $<0.0005$ to 0.01 ), and between the desert and all other types of open areas except for tundra ( $p$ from < 0.0005 to 0.003 ). Productivity of ground vegetation in forests and that in desert did not differ ( $p$ from 0.9 to 1.0 ). Productivity of tundra was significantly lower than that in the open areas in the zone of deciduous forests $(p$ from $<0.0005$ to 0.03 ). There was no significant correlation between the mean productivity of ground vegetation and the average standing crop of biomass in the nine vegetation types $(r=0.482, \mathrm{n}=9, p=0.2)$.

Average densities of small rodents in 14 vegetation types were low in deserts, all types of forests, and tundra ( $8-29$ rodents/ha, Fig. 3B). Natural open grasslands in the zones of mixed forests, deciduous forests, and in steppes were characterised by mean densities of $88-144$ rodents/ha. The highest average densities were recorded in the farmlands of temperate zone and steppe ( $308 \mathrm{inds} / \mathrm{ha}$ in alfalfa fields and $490 \mathrm{inds} / \mathrm{ha}$ in poorly harvested or unreaped corn fields in steppes) (Fig. 3B).

Differences between the 14 vegetation types accounted for $26 \%$ of the total variation in mean densities of rodents (one-way ANOVA, $F=7.621$, $\mathrm{df}=13$, $p<0.0005$ ). In pairwise comparisons, densities in farmlands in the zone of deciduous forests differed from those in deserts (both natural and cultivated areas), tundra, taiga (both vegetation types), mixed forests, deciduous forests, and 
farmland in the zone of mixed forests ( $p$ from< 0.0005 to 0.02 ). Densities in the farmlands in steppe differed from those in all other types of vegetation except for farmlands in the zone of deciduous forests ( $p$ from $<0.0005$ to 0.001 ).

Mean densities of rodents were related to productivity of ground vegetation (Fig. 3C) but were not to standing crop of biomass $\left(R^{2}=0.24, n=8, p=0.2\right)$. Also, the maximum densities of rodents reported from various vegetation types grew with increasing mean productivity $\left(Y=-79.46+135.20 X, R^{2}=0.90, n=8\right.$ vegetation types, $\mathrm{p}<0.0005)$ and were not related to the standing crop of biomass $\left(R^{2}=0.18\right.$, $p=0.3$ ). Obviously, high productivity of vegetation means fast renewal of food resources after grazing, and, in consequence, enables rodents to live in high densities.

In the Palearctic, reproductive season of rodents lasts from spring through summer, although winter breeding occurs during increase phase in all cyclic populations (Nikiforov 1956, Tast and Kaikusalo 1976), and it precedes outbreaks in the deciduous forests (Pucek et al. 1993). In the arctic, boreal and nemoral regions, autumn (post-breeding) densities of rodents are usually higher than spring (pre-breeding) densities (Fig. 1). At southern latitudes (Mediterranean region, steppe, desert), a mid-summer pause in reproduction occurs as a physiological consequence of water deficit in rodents (Alikina 1959, Pavlov 1959), and spring densities are usually higher than autumn ones (Fig. 1). The difference between mean densities sampled twice a year expressed as percent of the higher (post-breeding) densities was used as an index of seasonality of rodent density changes (Fig. 4). Irrespectively of the type of dynamics, the weakest seasonal changes in densities were found in the coolest (tundra, taiga) and the hottest (steppe, desert) biomes. Index of seasonality was highest in the temperate zone in both cyclic and

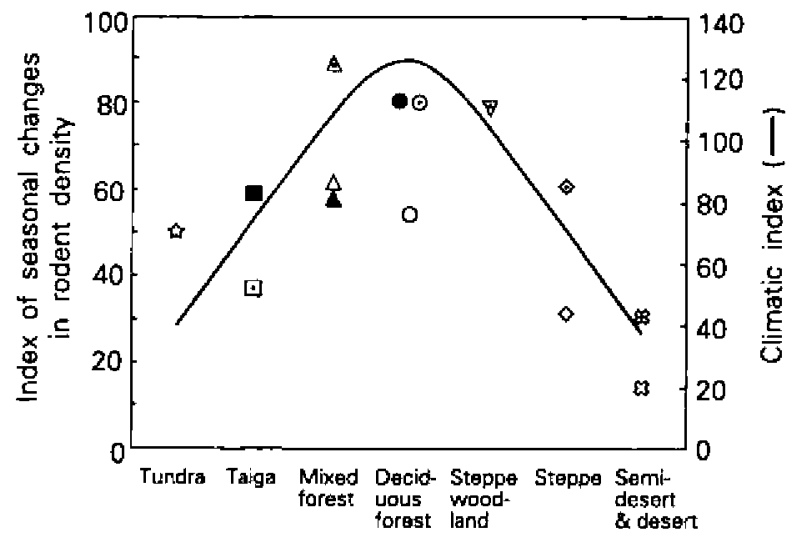

Fig. 4. Seasonal changes in rodent densities (dots) in relation to the climatic index (climate propitiousness for plant growth; line) in the Palearctic. Symbols of biomes and habitat types as in Fig. 2. Index of seasonal changes in rodent density: difference between mean autumn and mean spring density expressed as percent of post-breeding season density (autumn in arctic, boreal and temperate zones, and spring in steppe and desert). Sources of data as in Fig. 3. Climatic index: $T \times 0.01 P$, where $T^{*}$ - mean temperature of July (in ${ }^{\circ} \mathrm{C}$ ) and $P$ - mean annual precipitation (in mm) for each biome (values of $T$ and $P$ from Podbielkowski 1975 and Mityk 1978). 
non-cyclic rodents, which conformed to the geographic pattern of climate propitiousness for plant growth (Fig. 4). There was no correlation between mean indices of cyclicity and seasonal changes in rodent density in 14 habitat types $(r=0.27, n=14, p=0.3$ ).

\section{Role of predation in shaping rodent dynamics - hypotheses and results of empirical studies}

The hypothesis on the role of predation in driving the cycles or maintaining the non-cyclic fluctuations of rodents is based on the assumption of qualitatively different impact by specialist predators (weasel Mustela nivalis and stoat Mustela erminea that dominate among resident predators in the North) and generalist predators (fox Vulpes vulpes, buzzard Buteo buteo, tawny owl Strix aluco, and pine marten Martes martes that dominate at southern latitudes) (Hansson 1987, Hansson and Henttonen 1988, Hanski et al. 1991). The crucial assumptions of predator regulation hypothesis are: (1) specialist predators have destabilizing effect on rodent numbers through continued effective hunting of the few remaining rodents after the decline, and may drive rodent cycles by a substantial time lag in their numerical response (Andersson and Erlinge 1977, Hanski et al. 1993, Norrdahl 1995); (2) generalist predators in the presence of abundant alternative prey have stabilizing effect on rodent numbers because of an S-shaped functional response and fairly stable numbers, which in consequence are expected to produce density-dependent percent predation on rodents (Andersson and Erlinge 1977, Erlinge et al. 1984, 1988, Hansson 1987). However, this hypothesis can not explain rodent cycles in open grasslands and farmlands in the temperate zone, steppes and semideserts (where both numerous generalist and specialist predators are present, Jędrzejewski and Jędrzejewska 1993), nor are its basic assumptions supported by field research.

A long-term study in Finland (Kaikusalo 1982) showed no time lag in least weasel numerical response to the changes in abundance of cyclic rodents. In our 7-year study in deciduous forests (E Poland), where rodents show recurrent waves of outbreaks-crashes after mast years, a numerical response of weasels to changes in rodent numbers took place, without a time lag, in spring-summer seasons, when weasels reproduced (Jędrzejewski et al. 1995). Data obtained by Tapper (1979) and Korpimäki et al. (1991), who sought to document the time lag in weasel populations, were inconclusive because their methods were inadequate to test numerical responses.

Tapper (1979) collected weasel carcasses from January until June, so the sample represented the survival of the previous year weasels rather than the current year numbers. Reproduction parameters (percent females pregnant and mean number of embryos per pregnancy) were positively correlated with the rodent numbers in the same year, which indicates no time lag in weasel numerical response. 
Korpimäki et al. (1991) and Norrdahl (1995) snowtracked weasels in early and late winter on short transects (totally $0.5-2.5 \mathrm{~km}$ ) and trapped rodents in spring and autumn. They found that index of weasel abundance correlated with rodent abundance with 0.5 and 1-year delay. However, Korpimäki et al. (1991) did not census weasels in summer and thus missed the spring-summer increase and the yearly peaks of weasel numbers.

Our radio-tracking study on male weasels revealed that their home ranges increased from an average of 24 hectares during rodent outbreak in 1990 (300 rodents/ha) to 167 hectares during crash of rodents in the following year (10 rodents/ha) (Jędrzejewski et al. 1995). Parallelly, density and mobility of weasels greatly varied. From early winter 1990 till spring 1991, when rodents crashed, the density of weasels declined 7 times (from 5.1 to $0.7 \mathrm{ind} / \mathrm{km}^{2}$ ), whereas the mobility of male weasels (measured by number of tracks crossing a transect) increased 17 times (Jędrzejewski et al. 1995, and unpubl. data). We emphasize that tracking index can be a valuable measure of weasel abundance only as an auxiliary method, applied together with other techniques, such as live-trapping and radio-tracking.

Evidently, a short time lag in weasel response to changes in rodent numbers may occur, but especially careful methodology and year-round censusing is needed to document it. Our study (Jędrzejewski et al. 1995) and that by Tapper (1979), indicated that weasels adjust their breeding effort to spring numbers of rodents. In the decline phase of cyclic microtines, high spring numbers of voles are often followed by summer decline. In such years, a belated outbreak of weasels (in summer, ie few months after rodent peak) may occur and deepen the decline of voles (see eg Goszczyński's 1977 study on cyclic Microtus arvalis and Kucheruk and Dunaeva's 1948 observations on cyclic Microtus brandti). The long (9-month) time lag in the numerical response of weasels necessary to produce vole cycles (May 1981, Hanski et al. 1993) has not been found so far.

A one-year lag time in numerical response has only been observed in carnivores with delayed implantation: the pine marten in temperate forests (Zalewski $e t$ al. 1995), and the stoat in northern Finland (Kaikusalo 1982) and open habitats in Switzerland (Debrot 1983).

Other observations also create difficulties for the predation hypothesis. For instance, similar patterns of weasel predation have been reported for forest rodents in the deciduous forests with occasional outbreaks (Jędrzejewski et al. 1995), for a cyclic population of Microtus arvalis in the farmlands of central Europe (Goszczyński 1977), and for non-cyclic gerbils in the Turkmen deserts (Gorbunov 1983). On Wrangel Island, lemming populations cycle in absence of weasels, stoats and any predators specialised on rodents (Chernyavskiï and Dorogoï 1981).

In deciduous forests in E Poland, we found no qualitative difference between impact by generalist (tawny owls, pine martens) and specialist predators (weasels) (Fig. 5). Each of the three species exerted the heaviest impact at low and/or moderate densities of rodents. According to predator regulation hypothesis, this 


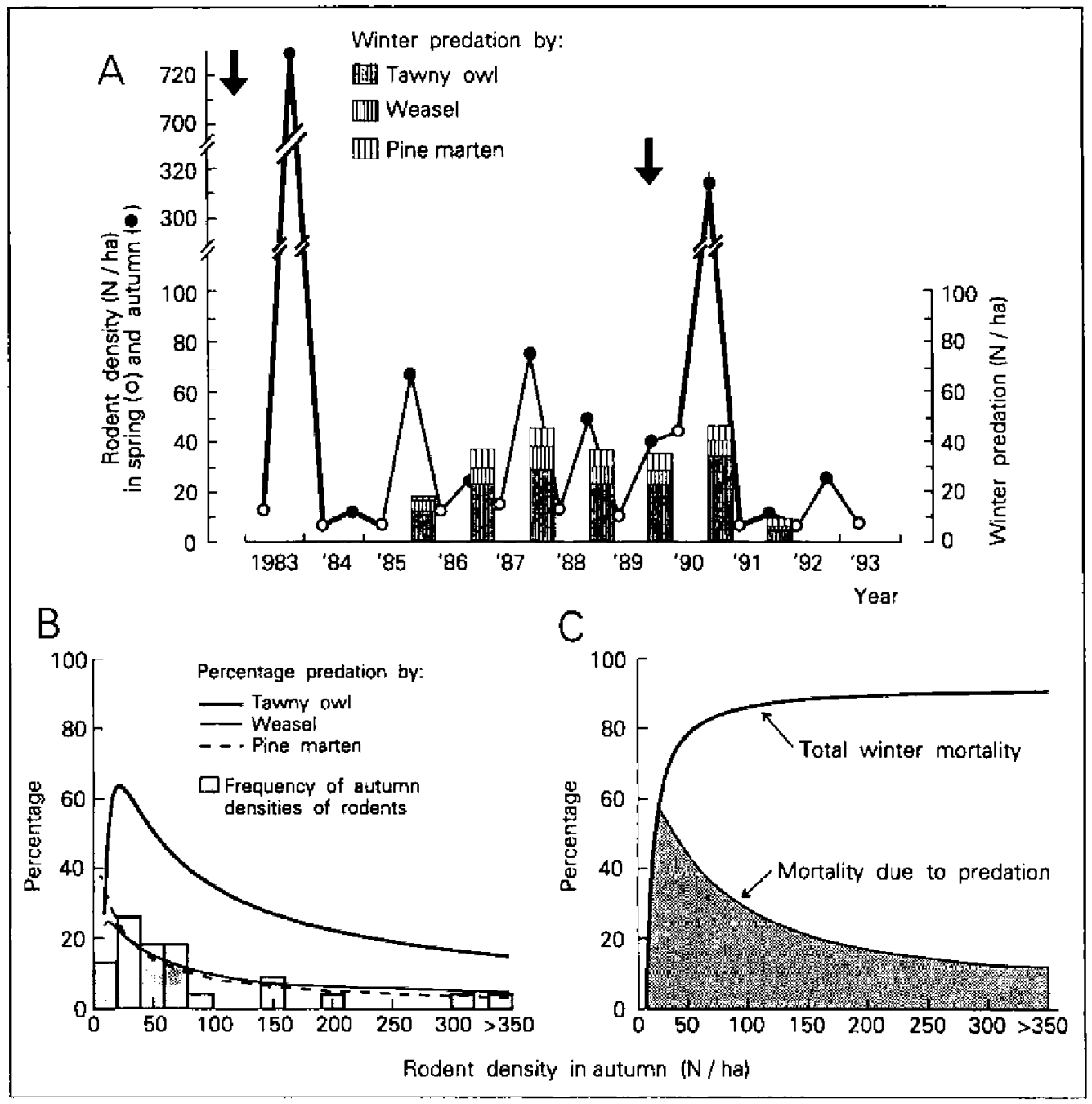

Fig. 5. The role of predation in the population dynamics of non-cyclic (but outbreaking at 6-9-year intervals in consequence of heavy crops of tree seeds) rodents in European deciduous forests (Biatowieża Forest, E Poland; combined numbers of Clethrionomys glareolus and Apodemus flavicollis). (A) Winter (1 October - 15 April) predation by three most numerous species of predators in relation to rodent densities (Jędrzejewski et al. 1995, 1996, Zalewski et al. 1995). In years of low densities, rodents still bred in autumn so the number of rodents removed by predators in winter was somewhat higher than density of rodents estimated in September/October. Arrows denote heavy crops of tree seeds. (B) Percentage predation by the three predators in winter in relation to autumn densities of rodents (Jędrzejewski et al. 1995, 1996, Zalewski et al. 1995). Percent predation by all species compared to the frequency distribution of autumn densities of rodents recorded during 23 years (Jędrzejewski et al. 1996, Pucek et al. 1993) appeared to peak at the most frequent densities. (C) Percentage winter mortality of rodents in relation to their autumn densities and the role of predation (combined effects of the three predators) in the total winter mortality (from Pucek et al. 1993). Total percentage predation (shaded area) calculated from empirical data (graph A) were corrected for overestimates of predation rates in years of low rodent densities. 
Table 1. Results of the study on predation on rodents in Bialowieża Primeval Forest (E Poland) compared to the predictions of predation regulation hypothesis (PRH). $(+)$ confirmation of hypothesis, $(-)$ results contradictory to the hypothesis.

\begin{tabular}{|c|c|c|c|c|}
\hline \multirow[b]{2}{*}{ Parameter } & \multicolumn{2}{|c|}{ Generalist predator } & \multicolumn{2}{|c|}{ Specialist predators } \\
\hline & Predicted by PRH & $\begin{array}{c}\text { Observed in } \\
\text { Biatowieża Forest }\end{array}$ & Predicted by PRH & $\begin{array}{c}\text { Observed in } \\
\text { Białowieża Forest }\end{array}$ \\
\hline $\begin{array}{l}\text { Dietary } \\
\text { response } \\
\text { to rodent } \\
\text { fluctuations }\end{array}$ & $\begin{array}{l}\text { Shift to alternative } \\
\text { prey, when rodents } \\
\text { scarse; S-shaped } \\
\text { functional response }\end{array}$ & $\begin{array}{l}\text { Continued hunting, } \\
\text { when rodents } \\
\text { scarse; Functional } \\
\text { response of } \\
\text { logarithmic type } \\
\qquad(-)\end{array}$ & $\begin{array}{l}\text { Continued hunting } \\
\text { when rodents scarse }\end{array}$ & $\begin{array}{l}\text { Continued hunting } \\
\text { when rodents scarse } \\
\qquad(+)\end{array}$ \\
\hline Numbers & Stable & $\begin{array}{l}\text { Fairly stable } \\
\text { numbers of tawny } \\
\text { owls; delayed } \\
\text { numerical response } \\
\text { (1-yr lag) by } \\
\text { martens } \\
\qquad(+/-)\end{array}$ & $\begin{array}{l}\text { Delayed numerical } \\
\text { response to rodent } \\
\text { fluctuations }\end{array}$ & $\begin{array}{l}\text { Numerical response } \\
\text { with no delay } \\
\qquad(-)\end{array}$ \\
\hline $\begin{array}{l}\text { Predation } \\
\text { impact } \\
\text { (\% predation) }\end{array}$ & $\begin{array}{l}\text { Density-dependent, } \\
\text { heaviest at high } \\
\text { rodent densities }\end{array}$ & $\begin{array}{l}\text { Inversely density- } \\
\text { dependent, heavy at } \\
\text { low numbers of } \\
\text { rodents (heaviest at } \\
\text { the most frequent } \\
\text { densities) } \\
\text { (-) }\end{array}$ & $\begin{array}{l}\text { Inversely density- } \\
\text { dependent, heaviest } \\
\text { at declining } \\
\text { numbers of rodents }\end{array}$ & $\begin{array}{l}\text { Inversely density- } \\
\text { dependent, heaviest } \\
\text { at low numbers of } \\
\text { rodents } \\
\text { (+) }\end{array}$ \\
\hline $\begin{array}{l}\text { Consequences } \\
\text { for rodent } \\
\text { populations }\end{array}$ & $\begin{array}{l}\text { Regulation } \\
\text { (stabilisation) of } \\
\text { rodent numbers }\end{array}$ & $\begin{array}{l}\text { Limitation of rodent } \\
\text { numbers, deepening } \\
\text { the crash } \\
\text { (-) }\end{array}$ & $\begin{array}{l}\text { Destabilisation, } \\
\text { driving the cycles }\end{array}$ & $\begin{array}{l}\text { Limitation of } \\
\text { rodent numbers, } \\
\text { deepening the crash } \\
\qquad(-)\end{array}$ \\
\hline
\end{tabular}

is expected of specialists (weasels), only. Moreover, at very low densities of rodents, predation by weasels was small as compared to that by tawny owls and pine martens, because weasels died or emigrated, whereas generalist predators, due to their ability to supplement diet with alternative prey, maintained fairly high numbers and continued to hunt rodents (Jędrzejewski et al. 1994, Zalewski et al. 1995). Both tawny owl and pine marten had functional response described by logarithmic function and not S-shaped one (Zalewski et al. 1995, Jędrzejewski et al. 1996). Thus, the role of generalists was quite reverse to that proposed by predator regulation hypothesis (Table 1 ).

Percentage predation by tawny owls on bank voles near Oxford (Southern and Lowe 1982) also declined with growing densities of voles. These two studies 
conducted in deciduous forests (in Białowieza and Oxford) showed that the predictions of predator regulation hypothesis on the role of generalist predators in non-cyclic rodent populations are not valid. In Bialowieża Forest, their predation was nearly constant over moderate and high densities of rodents and declined during crash years and soon after the crash, only (Fig. 5A). This produced an inverse density-dependence in percentage predation over most years (Fig. 5B). Predators maximally exploited the most frequent densities of rodents.

Sinclair (1989) defined the regulating factors as those acting in a direct density-dependent way, and limiting factors as those changing the level of densities. In deciduous forests in Poland, total percentage mortality of rodents in winter was density-dependent and had a strong regulatory impact, but percentage mortality caused by all predators was inversely density dependent (Fig. 5C). Similarly, Scandinavian studies (Erlinge et al. 1983, Erlinge 1987) have found that the total percentage mortality was density-dependent, and that heavy predation on rodents occurred. However, they have not shown that percentage predation acted in a density-dependent way. Thus, predation appears to be an important limiting, but not regulating factor. Other factors that cause density-dependent mortality have to act together with predation to stabilise rodents in deciduous forests.

In cyclic populations of rodents in all regions (from tundra to temperate grasslands to semideserts), different communities of predators exist. Nomadic avian predators often dominate such communities and can effectively seek areas with rodent peaks. They show strong numerical responses to changes in rodent abundance with practically no time lag (Kadochnikov 1953, Gibet 1960, Korpimäki 1994). Although these predators show some density dependence in the percentage of prey taken (Korpimäki and Norrdahl 1991a, b), they are not able to stabilize cyclic rodents in open habitats.

In conclusion, we propose that communities of predators can not change the type of dynamics, although they may be an important factor of mortality and can effectively lower densities of rodents. Thus, they act as a limiting, but not regulating, factor in rodent populations. This conclusion is consistent with manipulative experiments with predator exclusion (Schnell 1968, Erlinge 1987, Desy and Batzli 1989, Bock and Bock 1994).

\section{Discussion - interpretation of observed vegetation-rodents correlations as cause-effect relationships}

In the analysis and synthesis of the available empirical data we have demonstrated correlations between abundance of vegetation and patterns in rodent fluctuations in the Palearctic biomes. However, to interpret these correlations as cause-effect relationships, it would be necessary to evidence that the analysed measures of vegetation are directly linked to nutritional factors. We are aware of the fact that the two measures of ground vegetation used in this paper (standing 


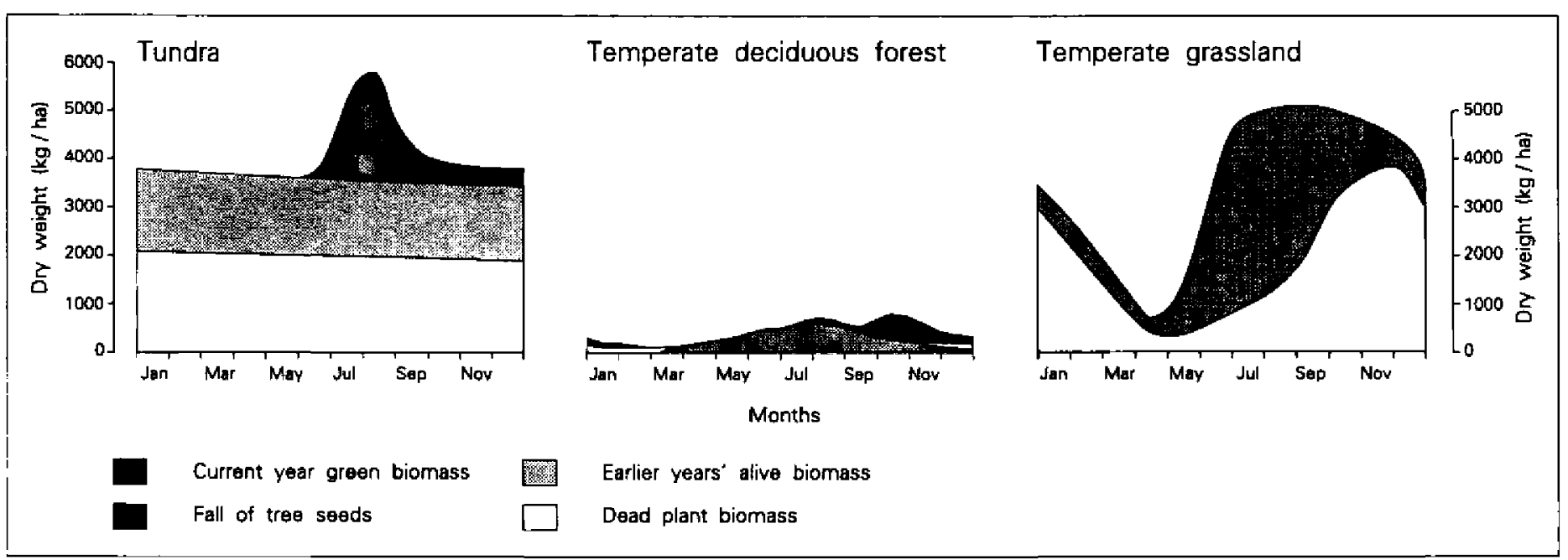

Fig. 6. Seasonal changes in the standing crop of biomass of ground vegetation in Fennoscandian tundra (Ostbye et al. 1975, Kjelvik and Kärenlampi 1975, Sandhaug et al. 1975), deciduous forests in Central Europe (Białowieża National Park, Poland; Dąbrowski 1953, Falińska 1971, Aulak 1976), and unmown grassland in the zone of deciduous forests in Central Europe (Ojców National Park, Poland; Jankowska 1967). 
crop of biomass and net productivity) are rough approximates of true quantity and quality of plants utilised by rodents. Nonetheless, we propose an explanation of the mechanisms of rodent population dynamics based on the observed phenomena.

Although equally high indices of cyclicity were found in all biomes with high standing crop of ground vegetation (tundra, grasslands and farmlands in the temperate zone), rodent cycles are somewhat different in each biome because of higher densities of rodents with increasing productivity, and seasonality. Plant productivity and biomass, rodent density, seasonality, and in consequence index of cyclicity are continuous variables. But for the sake of clarity, we will focus on three well defined examples (Fig. 6): (1) tundra (low densities of rodents, high cyclicity index, high biomass of vegetation, low productivity, weak seasonality), (2) grasslands in the temperate zone (high densities of rodents, high index of cyclicity, high biomass and productivity of vegetation, strong seasonality), (3) temperate deciduous forests (low densities of rodents, non-cyclic dynamics, low biomass and productivity of ground vegetation, strong seasonality). Adding a fourth example, the desert (low densities of non-cyclic rodents, low biomass and productivity, and weak seasonality), would practically complete the possible combinations of factors that shape rodent dynamics in the Palearctic.

A prerequisite for cycles is winter food abundant enough to enable rodents to continue an increase phase beyond one growing season (longer reproductive season or even winter breeding). In tundra, about $40-50 \%$ of alive vegetation is made up by earlier years' leaves and stems (Fig. 6). Thus, winter biomass of alive plants is very high: about half of the summer standing crop. Tundra vegetation supplies fair winter food (additionally well preserved by deep snow) to rodents, but due to relatively low productivity (and high proportion of low quality food, such as mosses and lichens), it offers limited possibility of spring-summer increase of rodent numbers.

Multiannual variation in vegetation abundance in tundra and taiga is shaped by both temperature and biological properties of northern plants. Plants need several summers (a certain threshold of accumulated degree-days) to build up reserves for flowering and fruiting (Kalela 1962). When these reserves are accumulated, the abundant flowering and mass production of berries and seeds occur and may cause increase phase of microtines in the following winter or spring (Laine and Henttonen 1983). In peak years, heavy grazing by rodents on all plants (even on bark of wooden stems) may strongly influence vegetation, especially seed and fruit production in the following year, and is conducive to synchronous decline of several species of rodents (Järvinen 1987). Food-related mechanism of northern cycle of rodent was proposed by Kalela (1962), and later, it was analysed and further developed by Hansson (1979), Laine and Henttonen (1983), and Järvinen (1987).

In grasslands of the temperate zone, vegetation is dominated by soft-tissued perennial monocotyledons, and standing crop of biomass is very high in summer (Fig. 6). Productivity is high, but the turnover is fast, too. In winter, the standing crop of alive biomass is $10-20 \%$ of that in summer, ie $100-400 \mathrm{~kg} / \mathrm{ha}$ of soft-tissued 
plants (which is still much more than in the temperate forests) and a lot of dead plant material serves as protective and insulative cover (Fig. 6). In steppes, $190-900 \mathrm{~kg}$ dry weight of green vegetation per hectare may overwinter under snow (Bazilevich and Shmakova 1984). Seasonal variation in the standing crop of biomass in the temperate grasslands is more pronounced than that in tundra and taiga. One consequence may be that the difference between mean spring and autumn densities of rodents is greater (Figs 1 and 4 ).

In the temperate and steppe grasslands, multiannual variation in the standing crop of biomass is very pronounced, because it does not rely on few years' accumulation of reserves, but on a current year productivity, which is shaped by temperature and precipitation in a given year. Temperature should be more important in the boreal and nemoral zone, whereas precipitation would be crucial in steppes and deserts. In 11-year studies on plant biomass in the steppe in Serpukhovskii region, near Oka river (Danilov 1988), summer standing crop of biomass varied nearly 5-fold (from 869 to $4089 \mathrm{~kg} / \mathrm{ha}$ ) in response, primarily, to variation in rainfall of the current spring (April-June). In grasslands, winter crop of biomass is a function of vegetation abundance in the previous summer (Bazilevich and Shmakova 1984), so summers with abundant biomass foster increase phase and peaks of rodents in the following year. At southern latitudes, where snow cover is shallow or absent, rodents often store large quantities of plant shoots and seeds for winter in deep burrows (Kucheruk and Dunaeva 1948, Krylova et al. 1954).

In temperate deciduous forests, ground vegetation is dominated by soft-tissued dicotyledons. In winter, standing crop of alive plants is very small, from $13 \mathrm{~kg} / \mathrm{ha}$ in beech forests to $100 \mathrm{~kg} / \mathrm{ha}$ in oak-hornbeam forests (20-30\% of summer standing crop; Kaźmierczakowa 1967, Aulak 1976). Thus, rodents may regularly face food shortage in winter and early spring. Their winter mortality is, on average, $80 \%$ and winter breeding is usually not possible. Such high, density-dependent mortality (Pucek et al. 1993) with no winter breeding prevents cycles and shapes seasonal fluctuations. However, tree seeds are important food resources for rodents in oak-beech and oak-hornbeam forests. The mechanism of masting in trees is analogous to that of seed/fruit production in tundra vegetation. Trees need several years to accumulate energy and nutrient reserves and during a particularly warm summer, they abundantly produce flower buds, which develop seeds in the following year. One or two years after masting, seed crop is nil or very poor. Mast years of oak Quercus robur occur at 6-9-year intervals synchronously over vast areas of the temperate forests (Pucek et $a l$. 1993). In winter after the fall of mast, forest rodents often breed, thus an outbreak begins. By the second winter, food supply is very poor and the crash of rodents takes place (Pucek et al. 1993). In forests with no masting species (eg ash-alder forests, birch forests, natural coniferous forests in the temperate zone, young stands not yet fruiting), rodents have only seasonal fluctuations with no recurrent waves of outbreaks and crashes.

Cycles of rodents in northern ecosystems and the recurrent waves of outbreaks and crashes in the oak/beech forests have rather regular periods because they 
depend on accumulation of energy reserves by plants. In contrary, in grasslands, fluctuations in plant abundance are due to immediate response by plants to weather conditions, so fluctuations of rodents are less regular there, although rodent-plant and rodent-disease interactions may contribute to periodicity of cycles in grasslands and farmlands (eg Kucheruk and Dunaeva 1948).

Non-cyclicity of rodents in deserts, where some vegetation is available during winter, has somewhat different mechanism than that in deciduous forests. The breeding of rodents pauses twice each year, in winter (cold season) and in mid-summer (drought). Thus prolonged increase phase of rodent numbers is not possible except for years with abundant rainfall. In such years, flourishing plant resources allow mid-summer reproduction and may cause outbreaks of rodent numbers in the following spring (Pavlov 1959, Marinina 1970, Dubyanskii and Dubyanskaya 1980).

Our proposed explanation for the geograhic pattern in cyclicity of rodents in the Palearctic region is consistent with experiments on food addition to rodent populations. Generally, supplementary food increased the densities and amplitude of fluctuations but did not decrease cyclicity (Andrzejewski 1975, Bujalska 1975, Cole and Batzli 1978, Taitt and Krebs 1981, Henttonen et al. 1987). This can be deduced from our Figs 2 and 3.

Finally, we emphasize that in the relationship between rodent cyclicity and the standing crop of ground vegetation in summer (shown in Fig. 2), the summer biomass of vegetation was used as an index of food resources for rodents in the following winter. Winter biomass is a function of previous summer biomass but in somewhat different way in each zone. It must be noted, that in places, where summer standing crop of vegetation is high but none or very little of it remains for winter (eg in ploughed fields after the harvest of annual crops, repeatedly mown meadows, grazed pastures), rodents do not cycle because of shortage of winter food (Truszkowski 1982). Thus, modern farming has been much relieved from 'mouse plagues' as compared to the medieval three-field system, which had fostered rodent outbreaks by annual fallowing of the one-third of area.

In conclusion, based on the most reliable long-term data collected by compatible methods in Europe and the former Soviet Union, we showed that:

(1) population dynamics of rodents in various biomes are linked to the standing crop of biomass of ground vegetation (high biomass means high cyclicity of rodents);

(2) the level of rodent densities is correlated with net productivity of ground vegetation;

(3) in all types of habitats and rodent dynamics, predation on rodents can be important factor of mortality, but seems unlikely to shape the pattern of rodent dynamics.

Acknowledgements: The study was financed by the budget of the Mammal Research lnstitute, Polish Academy of Sciences and by grant KBN 4441691 02. We thank Drs Z. Pucek, G. O. Batzli and an Anonymous Reviewer for comments and suggestions on the earlier draft. K. Zub prepared the figures and L. Szymura helped with computer data files. 


\section{References}

Agrell J., Erlinge S., Nelson J. and Sandell M. 1992. Body weight and population dynamics: cyclic demography in a noncyclic population of the field vole (Microtus agrestis). Canadian Journal of Zoology 70: 494-501.

Alekseev A. F. and Asenov G. A. 1976. [The influence of hydro-thermal regime on the reproduction of great gerbil in the north-west Kyzyl-Kum]. Ekologiya 1976(6): 89-91. [In Russian]

Alikina E. V. 1959. Influence of the metabolism on the ovo and spermatogenesis in the field voles (Microtus arvalis Pall. and Microtus socialis Pall.). Zoologicheskiï Zhurnal 38: 610-625. [In Russian with English summary]

Andersson M. and Erlinge S. 1977. Influence of predation on rodent populations. Oikos 29: 591-597.

Andrzejewski R. 1963. Processes of incoming, settlement and disappearance of individuals and variations in the numbers of snall rodents. Acta Theriologica 7: 169-213.

Andrzejewski R. 1975. Supplementary food and the winter dynamics of bank vole populations. Acta Theriologica 20: $23-40$.

Aulak W. 1970. Studies on herb layer prodaction in the Circaeo-Alnetum Oberd. 1953 association. Ekologia Polska 18: 411-427.

Aulak W. 1973. Production and energy requirements in a population of the bank vole, in a deciduous forest of Circaeo-Alnetum type. Acta Theriologica 18: 167-190.

Aulak W. 1976. Development and production of ground flora in Tilio-Carpinetum Tracz. 1962 association as one of the elements of basic trophic level in the forest ecosystems. Zeszyty Naukowe SGGW-AR, Rozprawy Naukowe 60: 1-151. [In Polish with English summary]

Babińska-Werka J. 1979. Effects of common vole on alfalfa crop. Acta Theriologica 24: 281-297.

Batzli G. O. 1992. Dynamics of small mammal populations: a review. [In: Wildlife 2001: Population. D. R. McCullough and R. H. Barret, eds]. Elsevier Applied Science, New York: 831-850.

Bazilevich N. I. and Shmakova E. I. 1984. Productivity of the completely reserved meadow steppe in the Central Chernozem Biosphere Reservation. Byulleten Moskovskogo Obshchestva Ispytateleï Prirody (Otdel Biologicheskii) 89(4): 94-107. [In Russian with English summary]

Begon M., Harper J. L. and Townsend C. R. 1986. Ecology. Individuals, populations and communities. Blackwell Scientific Publications, Oxford: 1-876.

Bernshtein A. D., Apekina N. S., Kopylova L. F., Myasnikov Yu. A. and Gavrilovskaya I. N. 1987. Comparative ecological and epizootological characteristics of Clethrionomys from the middle Cis-Ural region. Zoologicheskii Zhurnal 66: 1397-1407. [In Russian with English summary]

Bock C. E. and Bock J. H. 1994, Effects of predator exclusion on rodent abundance in an Arizona semidesert grassland. Southwestern Naturalist 39: 208-210.

Bondrup-Nielsen S. and Ims R. A. 1988. Demography during a population crash of the wood lemming, Myopus schisticolor. Canadian Journal of Zoology 66: 2442-2448.

Borisova I. V., Popova T. A., Gordeeva T. K. and Kazantseva T. I. 1983. [Composition, structure and productivity of the desert and desert-steppe communities (northern Gobi)]. Ekologiya 1983(3): 28-32. [In Russian]

Buchalczyk T., Gębczyńska Z. and Pucek Z. 1970. Numbers of Microtus oeconomus (Pallas, 1776) and its noxiousness in forest plantations. EPPO Publications, Series A, 58: 95-99.

Bujalska G. 1975. The effect of supplementary food on some parameters in an island population of Clethrionomys glareolus (Schreber, 1780). Bulletin de l'Academie polonaise des Sciences (Serie des sciences biologiques) $23: 23-28$.

Bulatova I. K. and Gorchakovskij P. L. 1974. [The standing crop of phytomass in the upper tundras of Northern Ural and its changes in the course of succession]. Ekologiya 1974(6): 29-36. [In Russian]

Butet A. and Leroux A. B. A. 1993. Effect of prey on a predator's breeding success. A 7-year study on common vole (Microtus arvalis) and Montagu's harrier (Circus pygargus) in a West France marsh. Acta Oecologica 14: 857-865. 
Chernyavskiî F. B. and Dorogoi V. I. 1981. IOn the role of predators in the dynamics of lemming numbers (on the example of the Wrangel Island)]. (In: [Ecology of mammals of North-East Siberia]). Izdatelstvo Nauka, Moskva: 32-50. [In Russian]

Chitty D. 1960. Population processes in the vole and their relevance to general theory. Canadian Journal of Zoology 38: 99-113.

Chong Kuk L. 1979. The structure and productivity of grass cover in the phytocenoses of forest-steppe oak forests. Byulleten Moskovskogo Obshchestva Ispytateleï Prirody (Otdel Biologicheskiï) 84(3): 77-82. [In Russian with English summary]

Christian J. J. 1950. The adreno-pituitary system and population cycles in mammals. Journal of Mammalogy 31: 247-259.

Cole F. R. and Batzli G. O. 1978. Influence of supplemental feeding on a vole population. Journal of Mammalogy 59: 809-819.

Danilov V. I. 1988. On the structure of the overground phytomass of the meadow steppe zones of the Russkaya Plain. Byulleten Moskovskogo Obshchestva Ispytateleï Prirody (Otdel Biologicheskii) 93(6): 51-60. [In Russiara with English summary]

Dabrowski M. J. 1953. The studies on the biomass of field-stratum carried on by the branch of IBL at Białowieża. Ekologia Polska 1: 45-56. [In Polish with English summaryl

Debrot S. 1983. Fluctuations de populations chez l'Hermine (Mustela erminea). Mammalia 47: $323-332$

Desy E. A. and Batzli G. O. 1989. Effects of food availability and predation on prairie vole demography: a field experiment. Ecology 70: 411-421.

Dombrovsky V. V. 1971. Principles of fluctuations in the abundance of Microtus arualis Pall. in natural foci of Tularemia in the Moscow province, associated with landscape features and human activity. Fauna i ekologiya gryzunov 10: 199-216. [In Russian with English summary]

Dubyanskii M. A. and Dubyanskaya L. D. 1980. [The alternative forcasting the great gerbil numbers on Bakanas Plateau]. Ekologiya 1980(4): 72-77. [In Russian]

Dybskaya T. I. 1964. The experiment of the quantitative estimation of vegetation in the nord sandy desert. Byulleten Moskovskogo Obshchestva Ispytatelei Prirody (Otdel Biologicheskii) 69(4): 86-100. [In Russian]

Elton C. S. 1924. Periodic fluctuations in the numbers of animals: their causes and effects. British Journal of Experimental Biology 2: 119-163.

Elton C. S. 1942. Voles, mice and lemmings. Clarendon Press, Oxford: 1-496.

Ernelianov P. F., Babenyshev V. P., Djmukhadze I. M., Tsikhistavi Sh. G., Uznadze I. A., Grachev G. V. and Vardoshvili G. G. 1972. Ecology of the common vole (Microtus arvalis) on the Djavakhetsky Mountain territory (Georgia). Zoologicheskiï Zhurnal 51: 891-898. [In Russian with English summary]

Erlinge S. 1987. Predation and noncyclicity in a microtine population in southern Sweden. Oikos 50: 347-352.

Erlinge S., Göransson G., Hansson L., Högstedt G., Liberg O., Nilsson I. N., Nilsson T., Schantz T., von and Sylvén M. 1983. Predation as a regulating factor on small rodent populations in southern Sweden. Oikos 40: 36-52.

Erlinge S., Güransson G., Högstedt G., Jansson G., Liberg O., Loman J., Nilsson I. N., Schantz T., von and Sylvén M. 1984. Can vertebrate predators regulate their prey? American Naturalist 123: $125-133$.

Erlinge S., Göransson G., Högstedt G., Jansson G., Liberg O., Loman J., Nilsson I. N., Schantz T, von and Sylvén M. 1988. More thoughts on vertebrate predator regulation of prey. American Naturalist 132: 148-154.

Falińska K. 1971. An estimate of diaspore production in the ecosystem of a mixed oak-hornbeam forest (Querco-Carpinetum) in the Bialowieża National Park. Ekologia Polska 19: 525-561.

Falinskj J. B. 1973. Herb layer filling by plant cormus in the Querco-Carpinetum community in the Białowieża National Park. Phytocoenosis 2(2): 123-142. 
Formozov A. N. 1948. [Small rodents and insectivores of the Sharinsk region of Kostroma district during the period 1930-1940]. Fauna i ekologiya gryzunov 3: 3-110. [In Russian]

Gibet L. A. 1960. [Numbers of raptors and their relationships with rodents in the steppe zone of northern Kazakhstan]. Ornitologiya 3: 278-291. [In Russian]

Gladkina T. S. 1968. The influence of the steppes inundation and enlargement of the area of cultivation upon distribution and numbers of harmful rodents of Azerbaijan. Zoologicheskii Zhurnal 47: 1840-1850. [In Russian with English summary]

Gorbunov A. V. 1983. [Changes in numbers of mustelids in the north-west Turkmenistan and south Ustyurt]. Proceedings of the Academy of Sciences of the Turkmen SSR, Series of Biological Sciences 4/1983: 51-56. [In Russian with Turkmen summary]

Gorchakovskii P. L. and Korobeinikova V. P. 1975. [Primary productivity of some meadow communities of the Southern Ural]. Ekologiya 1975(3): 5-17. [In Russian]

Goszczyński J. 1977. Connections between predatory birds and mammals and their prey. Acta Theriologica 22: $399-430$.

Hanski I., Hansson L. and Henttonen H. 1991. Specialist predators, generalist predators, and the microtine rodent cycle. Journal of Animal Ecology 60: 353-367.

Hanski I., Turchin P., Korpimäki E. and Henttonen H. 1993. Population oscillations of boreal rodents: regulation by mustelid predators leads to chans. Nature 364: 232-235.

Hansson L. 1971a. Estimates of the productivity of small mammals in a South Swedish spruce plantation. Annales Zoologici Fennici 8: 118-126.

Hansson L. 1971 b. Habitat, food and population dynamics of the field vole Microtus agrestis (L.) in south Sweden. Viltrevy 8: 267-378.

Hansson L. 1979. Food as a limiting factor for small rodent numbers. Tests of two hypotheses. Decologia 37: 297-314.

Hansson L. 1987. An interpretation of rodent dynamies as due to trophic interactions. Oikos 50: $308-318$.

Hansson $L$. and Henttonen $H$. 1985. Gradients in density variations of small rodents: the importance of latitude and snow cover. Oecologia 67: 394-402.

Hansson L. and Henttonen H. 1988. Rodent dynamics as community processes. Trends in Ecology and Evolution 3: 195-200.

Haukioja E. 1980. On the role of plant defences in the fluctuations of herbivore populations. Oikos 35: 202-213.

Henttonen H., Oksanen T., Jortikka A. and Haukisalmi V. 1987. How much do weasels shape microtine cycles in the northern Fennoscandian taiga? Oikos 50: 353-365.

Hörnfeldt B. 1994. Delayed density dependence as a determinant of vole cycles. Ecology 75: 791-806.

Ignatenko I. V. and Khakimzyanova F. I. 1971. [The soils and the standing crops of phytomass in Betula-Dryas and Salix tundras of East-European Northl. Ekologiya 1971(4): 17-24. [In Russian]

Jankowska K. 1967. Seasonal changes of vegetation and net primary production on the fresh meadow Arrhenatheretum elatoris. Studia Naturae, Seria A 1967(1): 153-173. [In Polish with English summary?

Järvinen A. 1987. Microtine cycles and plant production: what is cause and effect? Oikos 49: 352-357.

Jensen T. S. 1982. Seed production and outbreaks of non-cyclic rodent populations in deciduous forest.s. Oecologia 54: 184-192.

Jędrzejewski W. and Jędrzejewska B. 1993. Predation on rodents in Białowieża primeval forest, Poland. Ecography 16: 47-64.

Jędrzejewski W., Jędrzejewska B. and McNeish E. 1992. Hunting success of the weasel Mustela niualis and escape tactics of forest radents in Białowieża National Park. Acta Theriologica 37: $319-328$.

Jędrzejewski W., Jędrzejewska B., Zub K., Ruprecht A. L. and Bystrowski C. 1994. Resource use by Tawny owls Strix aluco in relation to rodent fluctuations in Białowieza National Park, Poland. Journal of Avian Biology 25; 308-318. 
Jędrzejewski W., Jędrzejewska B. and Szymura L. 1995. Weasel population response, home range, and predation on rodents in a deciduous forest in Poland. Ecology 76: 179-195.

Jędrzejewski W., Jędrzejewska B., Szymura A. and Zub K. 1996. Tawny owl (Strix aluco) predation in a pristine deciduous forest (Bialowieża National Park, Poland). Journal of Animal Ecology 65: $105-120$.

Kadochnikov N. P. 1953. [On the relationships between birds of prey and the social vole in the steppe Azerbaijan]. Zoologicheskii Zhurnal 32: 1222-1233. [In Russian]

Kaikusalo A. 1982. Predatory mammals and vole populations in the fell regions of north-west Finland. Soumen Riista 29: 89-92. [In Finnish with English summary]

Kalabukhov N. I. 1949. [The importance of rodents as a factor of foci of some infections!. Zoologicheskil Zhurnal 28: 389-406. [In Russian]

Kalela $O .1962$. On the fluctuations in the numbers of arctic and boreal small rodents as a problem of production biology. Annales Academiae Scientiarum Fennicae, Series A, N. Biologica 66: 1-38.

Karaseva E. V. 1960. The peculiarities of stational distribution of Microtus arualis Pall and the significance of various stations in its life span in the central districts of the Russian Federation. Fauna i ekologiya gryzunov 6: 27-55. [In Russian with English summary)

Kazanskii K. A. 1930. [The Soviet expedition on plant protection against agricultural pests in Mongolia (The biology and the experience in control of the vole Microtus brandti)]. Verkhneudinsk. [In Russian]

Kaźmierczakowa R, 1967. Ecology of primary production and phenology of the beech stand Fagetum carpaticum ground flora. Studia Naturae, Seria A 1967(1): 95-114. [In Polish with English summary]

Kjelvik S. and Kärenlampi L. 1975. Plant biomass and primary production of Fennoscandian subarctic and subalpine forests and of alpine willow and heath ecosystems. [In: Fennoscandian tundra ecosystems. Part 1. Plants and microorganisms. F. E. Wielgolaski, ed]. Springer-Verlag, Berlin: 111-120.

Kochev K. and Traczyk T. 1974. Primary production of Chrysopogon gryllus-Andropogon ischaemum pasture in Sofia region, Bulgaria. Ekologia Polska 22: 133-143,

Korpimäki E. 1994. Rapid or delayed tracking of multi-annual vole cycles by avian predators? Journal of Animal Ecology 63: 619-628.

Korpimäki E. and Norrdahl K. 1991a. Do breeding nomadic avian predators dampen population fluctuations of small mammals? Oikos 62: 195-208.

Korpimäki E. and Norrdahl K. 1991b. Numerical and functional responses of kestrels, short-eared owls, and long-eared owls to vole densities. Ecology 72: 814-826.

Korpimäki E., Norrdahl K. and Rinta-Jaskari T. 1991. Responses of stoats and least weasels to fluctuating food abundances: is the low phase of the vole cycle due to mustelid predation? Oecologia 88: $552-561$.

Krebs C. J. 1972, Ecology. The experimental analysis of distribution and abundance. Harper and Row Publishers, New York: 1-694.

Krebs C. J. and Myers J. H. 1974. Population cycles in small mammals. Advances in Ecological Research 8: 267-399.

Krylova K. T., Shilova E. S. and Shilov M. N. 1954. [Characteristies of ecology of the great gerbil (Rhombomys opimus Licht.) during the cold season in the conditions of north Aral Sea region]. Byulleten Moskovskogo Obshchestva Ispytateleï Prirody (Otdel Biologicheskii) 59(2): 3-14. [In Russian]

Kucheruk V. V. and Dunaeva T. N. 1948. [Data on dynamics of numbers of the Brandt vole (On the influence of epizooty on population)]. Fauna i ekologiya gryzunov 3: 111-178. [In Russian]

Kudryashova L. M. 1975. [Fluctuations in the bank vole numbers in Oka river valey in 1967-1973] Trudy Okskogo Gosudarstvennogo Zapovednika 11: 234-254. [In Russian]

Laine K. and Henttonen H. 1983. The role of plant production in microtine cycles in northern Fennoscandia. Oikos 40: 407-418 
Lavrova M. J. and Lebedeva T. S. 1962. The leptospirosis epizooty observed in the labelled mouse-shaped rodents in the lower course of the Kuban. Byulleten Moskovskogo Obshchestva Ispytatelei Prirody (Otdel Biologicheskiï) 67(1): 7-14. [In Russian with English summary]

Lidicker W. Z. 1988. Solving the enigma of microtine 'cycles'. Journal of Mammalogy 69: 225-235.

Lien L., Ostbye E., Hagen A., Skar H..J. and Svalastog D. 1975. Density variations of bird populations in high mountain habitats, Hardangervidda. [In: Fennoscandian tundra ecosystems. Part 2. Animals and systems analysis. F. E. Wielgolaski, ed]. Springer-Verlag, Berlin: 105-110.

Lieth H. 1975. Primary production of the major vegetation units of the world. [In: Primary productivity of the Biosphere. H. Lieth and R. H. Whittaker, eds]. Springer-Verlag, New York: 203-215.

Lindström E. R. 1994, Vole cycles, snow depth and fox predation. Oikos 70: 156-160.

Liro A. 1974. Renewal of burrows by the common vole as the indicator of its numbers. Acta Theriologica 19: 259-272.

Mackin-Rogalska R. and Nabagto L. 1990 . Geographical variation in cyclic periodicity and synchrony in the common vole, Microtus arvalis. Oikos 59: $343-348$.

Marcström V., Höglund N. and Krebs C. J. 1990. Periodic fluctuations in small mammals at Boda, Sweden from 1961 to 1988. Journal of Animal Ecology 59: 753-761.

Marinina L. S. 1970. [On the reproduction of the great gerbil (Rhombomys opimus Licht) in the central Kara Kum]. Proceedings of the Academy of Sciences of the Turkmen SSR, Series of Biological Sciences 1/1970: 46-52. [In Russian with English summary]

May R. M. 1981. Models for single populations. In: Theoretical ecology. Principles and applications. 2nd edition, R. M. May, ed]. Blackwell Scientific Publications, Oxford: 5-77.

Mezhzherin V. A. and Mikhalevich O. A. 1983. [Relationships between population density of smal] rodents and their food base]. Ekologiya 1983(5): 49-66. [In Russian]

Mityk J. 1978. [Physica] geography of the World]. Państwowe Wydawnictwo Naukowe, Warszawa: 1-503. [In Polish]

Muntyanu A. and Sitnik V. 1994. Spatial structure of Microtus rossiaemeridionalis during population growth. Polish ecological Studies 20: 257-263.

Murdoch W. W, and Oaten A. 1975. Predation and population stability. Advances in Ecological Research 9: 1-130.

Myasnikov Yu. A. 1976. The distribution and population dinamics of rodents, Lagomorpha and Insectivores species in the Tulskaya Oblast. Fauna i ekologiya gryzunov 13: 164-236. In Russian with English summary]

Myllymäki A. 1977. Demographic mechanisms in the fluctuating populations of the field vole Microtus agrestis. Oikos 29: $468-493$.

Naumov N. P. 1948. |An outline of the comparative ecology of small rodents]. Izdatelstvo Akademii Nauk SSSR, Moskva: 1-203. [In Russian]

Nikiforov L. P. 1956. [On the winter reproduction of narrow-headed voles in Kurgan steppe woodland], Zoologicheskiï Zhurnal 35: 464-466. [In Russian]

Norrdahl K. 1995. Population cycles in northern small mammals. Biological Reviews of the Cambridge Philosophical Society 70: 621-637.

Oksanen L. and Oksanen T. 1992. Long-term microtine dynamics in north Fennoscandian tundra: the vole cycle and the lemming chaos. Ecography 15: 226-236.

O'Neill R. V. and DeAngelis D. L. 1981. Comparative productivity and biomass relations of forest ecosystems. [In: Dynamic properties of forest ecosystems. D. E. Reichle, ed]. Cambridge University Press, Cambridge: 411-449.

Ostapuk V. P., Tolkach V. N., Strelkov A. Z., Martysevich V. V. and Dvorak L. E. 1989. [Biological productivity of ash forests]. Zapovedniki Belorussii 13: 56-62. [In Russian]

Ostbye E., Berg A., Blehr O., Espeland M., Gaare E., Hagen A., Hesjedal O., Hagvar S., Kjelvik S., Lien L., Mysterud I., Sandhaug A., Skar H.-J., Skartveit A., Skre O., Skogland T., Solhoy T., Stenseth N. C. and Wielgolaski F. E. 1975. Hardangervidda, Norway. [In: Structure and function of tundra ecosystems. T. Rosswall and O. W. Heal, eds]. Ecological Bulletins (Stockholm) 20: 225-264. 
Pavlov A. N. 1959. Reproduction peculiarities of Meriones meridianus Pall. and $M$. tamariscinus Pall. under the conditions of the north-western Caspian territory. Zoologicheskii Zhurnal 38: 1876-1885. [In Russian with English summary]

Petrov P. A. and Rozhkov A. A. 1963. Many year fluctuations of abundance of small mouse-like rodents in Ilmen and Marine Territory landscape-ecological regions of North-West Caspian territory. Zoologicheskii Zhurnal 42: 914-925. [In Russian with English summary]

Pitelka F. A. and Schultz A. M. 1964. The nutrient-recovery hypothesis for arctic microtine cycles. [In: Grazing in terrestrial and marine environments. D. J. Crisp, ed]. Blackwell Scientific Publications, Oxford: $55-68$.

Plewczyńska U. 1970. Herb layer production and plant fall in the association Pino-Quercetum, Kozlowska 1925 in the Pisz Forest. Ekologia Polska 18: 757-778.

Podbielkowski Z. 1975. [Vegetation of Earth!. Wydawnictwa Szkolne i Pedagogiczne, Warszawa: 1-280. [In Polish]

Pucek Z., Jędrzejewski W., Jędrzejewska B. and Pucek M. 1993. Rodent population dynamics in a primeval deciduous forest (Bialowieża National Park) in relation to weather, seed crop, and predation. Acta Theriologica 38: 199-232.

Rapoport L. P. and Semenova N. I. 1962. IOn the variation in numbers of gerbils and small rodents in Fergana regions of Kirghizia]. Izvestia Akademii Nauk Kirgizskoï SSR, Seria Biologicheskikh Nauk 4(1): 41-48. [In Russian]

Romankow-Zmudowska A. and Grala B. 1994. Occurrence and distribution of the common vole, Microtus arvalis (Pallas), in legumes and seed grasses in Poland between 1977 and 1992. Polish ecological Studies 20: 503-508.

Ryszkowski L., Goszczyúski J. and Truszkowski J. 1973. Trophic relationships of the common vole in cultivated fields. Acta Theriologica 18: 125-165.

Sandell M., Agrell J., Erlinge S. and Nelson J. 1991. Adult philopatry and dispersal in the field vole Microtus agrestis. Oecologia 86: 153-158.

Sandhaug A., Kjelvik S. and Wielgolaski F. E. 1975. A mathematical simulation model for tundra ecosystems. [In: Fennoscandian tundra ecosystems. Part 2. Animals and system analysis. F. E. Wielgolaski, ed]. Springer-Verlag, Berlin: 251-266.

Schnell J. H. 1968. The limiting effects of natural predation on experimental cotton rat populations. Journal of Wildlife Management 32: 698-711.

Shcherbina E. I., Tashliev A. O. and Sukhinin A. I. 1980. The role of carnivorous mammals and birds of prey in controlling the abundance of gerbils. Fauna i ekologiya gryzunov 14: 150-157. [In Russian with English summary]

Semenov-Tyan-Shanskiï O. 1970. Population cycles in red-backed voles. Byulleten Moskovskogo Obshchestva Ispytateleï Prirody (Otdel Biologicheskiii) 75(2): 11-26. [In Russian with English summary]

Semenov-Tyan-Shanskiت O. 1972. The Norwegian lemming in the Lapland Reserve in 1968-1971. Byulleten Moskovskogo Obshchestva Ispytateleï Prirody (Otdel Biologicheskiï) 77(3): 32-45. [In Russian with English summary]

Shilov I. A., Kaletskaya M. L., Ivashkina I. N. and Soldatova A. N. 1977. The dynamics of the abundance of Microtus oeconomus Pall, in the Darwin Nature Reserve. Byulleten Moskovskogo Obshchestva Ispytateleï Prirody (Otdel Biologicheskiï) 82(5): 10-20. [In Russian with English summary]

Sirclair A. R. E. 1989. Population regulation in animals. [In: Ecological concepts. J. M. Cherrett, ed]. Blackwell Scientific Publications, Oxford: 197-241.

Smirin Yu. M. 1964. Population dynamics of rodents in different forest types in the localities near Moscow (Podmoskovye). Zoologicheskii Zhurnal 43: 1544-1551. [In Russian with English summary]

Southern H. N. and Lowe V. P. W. 1982. Predation by Tawny owls (Strix aluco) on bank voles (Clethrionomys glareolus) and wood mice (Apodemus syluaticus). Journal of Zoology, London 198: 83-102. 
Stavrovskiï D. D. 1989. [Dynamics of numbers of small rodents in the forests of Berezina Reserve]. Zapovedniki Belorussii 13: 120-125. [In Russian]

Straka F. and Gerasimov S. 1971. Correlations between some climatic factors and the abundance of Microtus arvalis in Bulgaria. Annales Zoologici Fennici 8: 113-116.

Sviridenko P. A. 1972. Apodemus agrarius Pall. under conditions of the Ukraine. Communication II. Variation in quantity. Vestnik zoologii 1972(1): 76-78. [In Russian with English summary]

Taitt M. and Krebs C. J. 1981. The effect of extra food on small rodent populations: II. Voles (Microtus townsendii). Journal of Animal Ecology 50: 125 137 .

Tapper S. 1979. The effect of fluctuating vole numbers (Microtus agrestis) on a population of weasels (Mustela nivalis) on farmland. Journal of Animal Ecology 48: 603-617.

Tarasov M. P. 1983. Materials on Microtus arvalis ecology in the central Precaucasus. Byulleten Moskovskogo Obshchestva Ispytateleï Prirody (Otdel Biologicheskiii) 88(1): 45-52. [In Russian with English summary]

Tast J. and Kaikusalo A. 1976. Winter breeding of the root vole, Microtus oeconomus, in 1972/1973 at Kilpisjärvi, Finnish Lapland. Annales Zoologici Fennici 13: 174-178.

Titlyanova A. A. and Nurmedov S. S. 1982. (Production-decomposition processes and balance of vegetation material in the desert ecosystem of western Turkmenia]. Ekologiya 1982(3): 31-37. IIn Russian]

Traczyk T. 1967. Studies on herb layer production estimate and the size of plant fall. Ekologia Polska 15: $837-867$.

Traczyk T. 1971. Productivity investigation of two types of meadows in the Vistula valley. I. Geobotanical description and primary production. Ekologia Polska 19: 93-106.

Traczyk T., Traczyk H. and Moszyńska B. 1973. Herb layer production of two pinewood communities in the Kampinos National Park. Ekologia Polska 21: 37-55.

Tropin N. N. 1963. On the action of unfavourable conditions of existence upon the gerbils Meriones meridianus Pall. and $M$. tamariscinus Pall. in the south-east of Volga-Ural sands. Zoologicheskii Zhurnal 42: 1252-1256. [In Russian with English summary]

Truszkowski J. 1982. The impact of the common vole on the vegetation of agroecosystems. Acta Theriologica 27: 305-345.

Vitala J. 1987. Social organization of Clethrionomys rutilus (Pall,) at Kilpisjärvi, Finnish Lapland. Annales Zoologici Fennici 24: 267-273.

Vilchek G. E. 1986. [Productivity of some phytocoenoses in Vorkuta tundras]. Ekologiya 1986(2): 8-13. [In Russian]

Weiner J., Grodziński W., Górecki A. and Perzanowski K. 1982a. Standing crop and above-ground production of vegetation in arid Mongolian steppe with Caragana. Polish ecological Studies 8 : 23-29.

Weiner J., Górecki A. and Zieliński J. 1982b. The effect of rodents on the rate of matter and energy cycling in ecasystem of arid steppe of central eastern Mongolia. Polish ecological Studies 8: 69-86.

Wijngaarden A., van 1957. The mammal fauna of two Betuwe landscapes. Mammalia 21: 267-300.

Yankova N. A. 1969. Biological productivity of some steppe phytocoenoses in the central part of the Crimean foothills. Byulleten Moskovskogo Obshchestva Ispytateleï Prirody (Otdel Biologicheskiii) 74(4): 136-140. [In Russian with English summary]

Zablotskaya L. B. 1971. [The dynamics of species structure of small rodent populations in the coniferous forests near Oka river, Moscow District]. Trudy Prioksko-Terrasnogo Gosudarstvennogo Zapovednika 5: 146-160. [In Russian]

Zalewski A., Jędrzejewski W. and Jędrzejewska B. 1995. Pine marten home ranges, numbers and predation on vertebrates in a deciduous forest (Bialowieża National Park, Poland). Annales Zoologici Fennici 32: 131-144

Received 1 December 1995, accepted 7 February 1996. 
Appendix I. Data on standing crop of biomass of ground vegetation and net productivity of ground vegetation in the main habitat types in seven biomes of the Palearctic region analysed in this study. Habitat types: (i) forests, (ii) natural and seminatural open areas (tundra, steppe, desert, unmown meadows and sedge marshes in the temperate zone), and (iii) farmlands (wintercrops). ${ }^{\text {a }}$ this value includes both the mean biomass (productivity) of ground vegetation and the average annual fall of tree seeds of $1109 \mathrm{~kg} / \mathrm{ha}$ (SD 1674), calculated from the following data: 1923,159 , and $147 \mathrm{~kg} / \mathrm{ha}$ (from Falińska 1971; $53^{\circ} \mathrm{N}-24^{\circ} \mathrm{E}$ ), 92, 516, 753, 4979, and $306 \mathrm{~kg} / \mathrm{ha}$ (from Mezhzherin and Mikhalevich $1983 ; 50^{\circ} \mathrm{N}-32^{\circ} \mathrm{E}$ ).

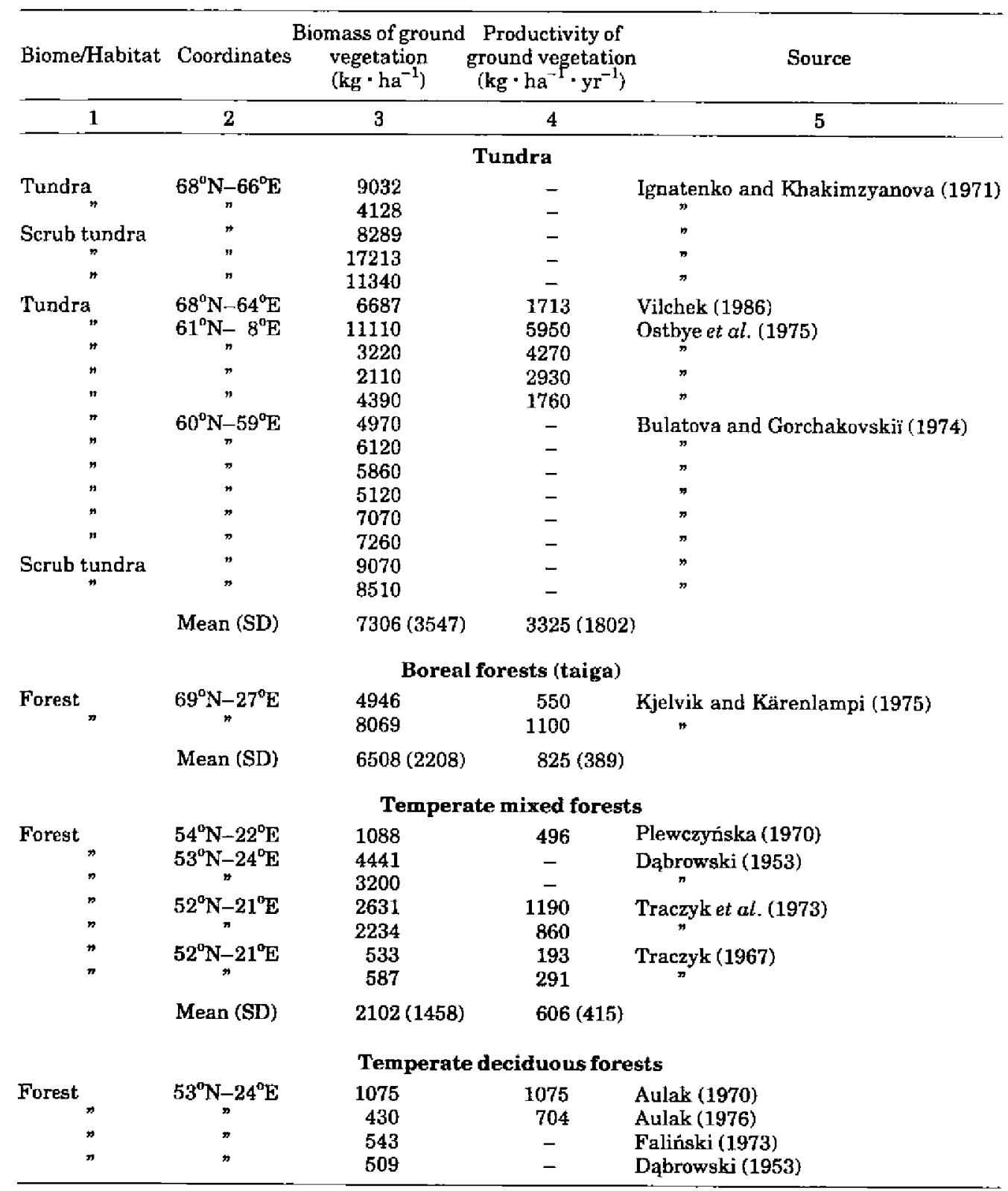




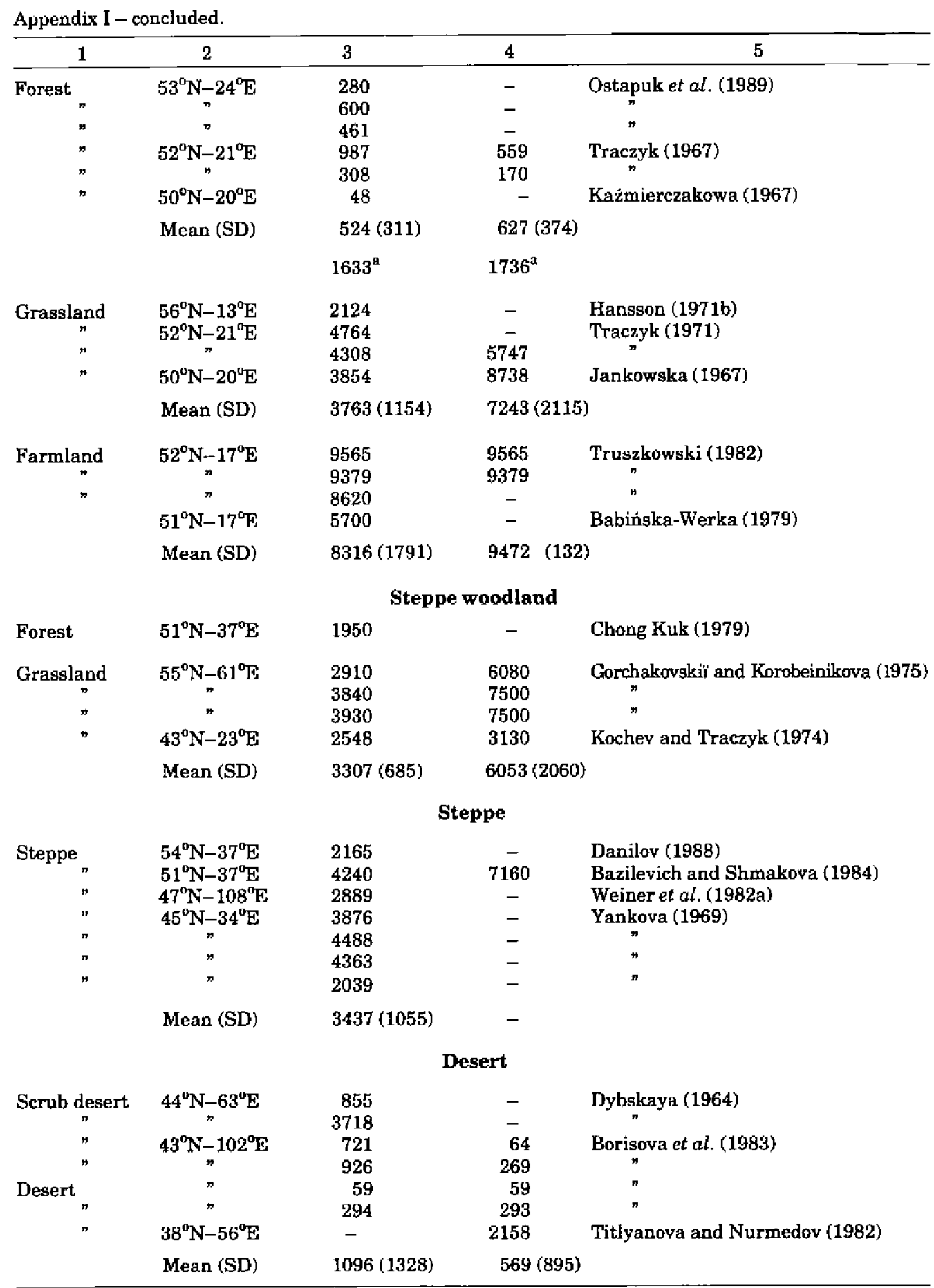


Appendix II. Data on rodent dynamics patterns used for the analysis of cyclicity. Abbrevations of rodent Latin names are the first two letters of the genus name and three letters of the species name. Biomes and habitats as in Appendix I.

\begin{tabular}{|c|c|c|c|c|c|}
\hline $\begin{array}{l}\text { Biomel } \\
\text { Habitat }\end{array}$ & Coordinates & Species of rodents & $\begin{array}{l}\text { N years } \\
\text { of trapping }\end{array}$ & $\begin{array}{l}\text { Cyclicity } \\
\text { index }\end{array}$ & Source \\
\hline 1 & 2 & 3 & 4 & 5 & 6 \\
\hline \multicolumn{6}{|c|}{ Tundra } \\
\hline Tundra & $70^{\circ} \mathrm{N}-24^{\circ} \mathrm{E}$ & Clruf & 13 & 0.60 & Oksanen and Oksanen (1992) \\
\hline$"$ & $69^{\circ} \mathrm{N}-21^{\circ} \mathrm{E}$ & Clruf, Clrut, Miagr, Lelem & 33 & 0.70 & Laine and Henttonen (1983) \\
\hline 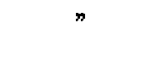 & $68^{\circ} \mathrm{N}-32^{\circ} \mathrm{E}$ & Clruf, Clrut, Clgla, Lelem & 31 & 0.78 & $\begin{array}{l}\text { Semenov-Tyan-Shanskii } \\
(1970,1972)\end{array}$ \\
\hline \multirow[t]{2}{*}{$"$} & $61^{\circ} \mathrm{N}-8^{\circ} \mathrm{E}$ & Lelem, Mipec, Clruf & 5 & 1.41 & Lien et al. (1975) \\
\hline & \multicolumn{3}{|c|}{ Mean (SD) } & \multicolumn{2}{|c|}{$0.873(0.366)$} \\
\hline \multicolumn{6}{|c|}{ Boreal forests (taiga) } \\
\hline Forest & $68^{0} \mathrm{~N}-24^{0} \mathrm{E}$ & $\begin{array}{l}\text { Clgla, Clrut, Clruf, } \\
\text { Miagr, Lelem }\end{array}$ & 16 & 0.86 & Henttonen et al. (1987) \\
\hline$n$ & $64^{0} \mathrm{~N}-20^{\circ} \mathrm{E}$ & Clgla, Clruf, Miagr & 18 & 0.54 & Hörnfeldt (1994) \\
\hline$"$ & $63^{0} \mathrm{~N}-23^{\circ} \mathrm{E}$ & Clgla, Miagr, Miepi & 11 & 0.71 & $\begin{array}{l}\text { Korpimäki and Norrdahl } \\
\text { (1991a, b) }\end{array}$ \\
\hline$n$ & $61^{\circ} \mathrm{N}-17^{\circ} \mathrm{E}$ & Clgla, Miagr & 28 & 0.55 & Marcström et al. (1990) \\
\hline$n$ & $61^{\circ} \mathrm{N}-12^{\circ} \mathrm{E}$ & Mysch, Clgla, Miagr & 8 & 0.98 & Bondrup-Nielsen and Ims (1988) \\
\hline \multicolumn{4}{|c|}{ Mean (SD) } & \multicolumn{2}{|c|}{$0.728(0.193)$} \\
\hline Grassland & $60^{\circ} \mathrm{N}-15^{\circ} \mathrm{E}$ & Miagr & 19 & 0.65 & Lindström (1994) \\
\hline Farmland & $63^{\circ} \mathrm{N}-23^{\circ} \mathrm{E}$ & Miagr, Miepi, Clgla & 11 & 0.38 & $\begin{array}{l}\text { Korpimaki and Norrdahl } \\
(1991 a, b)\end{array}$ \\
\hline \multicolumn{6}{|c|}{ Temperate mixed forests } \\
\hline Forest & $58^{\circ} \mathrm{N}-46^{\circ} \mathrm{E}$ & Clgla, Clrut, Clruf & 11 & 0.37 & Formozov (1948) \\
\hline$n$ & $57^{\circ} \mathrm{N}-54^{\circ} \mathrm{E}$ & Clgla, Clrut & 13 & 0.24 & Bernshtein et al. (1987) \\
\hline$"$ & $56^{\circ} \mathrm{N}-37^{\circ} \mathrm{E}$ & Clgla, Apfla & 7 & 0.21 & Smirin (1964) \\
\hline$"$ & $55^{\circ} \mathrm{N}-37^{0} \mathrm{E}$ & Clgla, Apfla, Apsyl, Apagr & 19 & 0.30 & Zablotskaya (1971) \\
\hline$"$ & $55^{\circ} \mathrm{N}-28^{\circ} \mathrm{E}$ & Clgla, Miagr, Miepi, Apfla & 14 & 0.20 & Stavrovskiï (1989) \\
\hline \multicolumn{4}{|c|}{ Mean (SD) } & \multicolumn{2}{|c|}{$0.264(0.071)$} \\
\hline Grassland & $59^{\circ} \mathrm{N}-38^{\circ} \mathrm{E}$ & Mioec & 8 & 0.51 & Shilov et al. (1977) \\
\hline Farmland & $55^{\circ} \mathrm{N}-38^{\circ} \mathrm{E}$ & Miarv & 21 & 0.68 & $\begin{array}{l}\text { Karaseva (1960), Dombrovsky } \\
\text { (1971) }\end{array}$ \\
\hline \multicolumn{6}{|c|}{ Temperate deciduous forests } \\
\hline Forest & $57^{\circ} \mathrm{N}-10^{\circ} \mathrm{E}$ & Clgla, Apfla & 9 & 0.23 & Jensen (1982) \\
\hline$n$ & $55^{\circ} \mathrm{N}-41^{\circ} \mathrm{E}$ & Clgla & 7 & 0.34 & Kudryashova (1975) \\
\hline$n$ & $53^{\circ} \mathrm{N}-24^{\circ} \mathrm{E}$ & Clgla, Apfla & 21 & 0.31 & Pucek et al. (1993) \\
\hline$"$ & $52^{\mathrm{D}} \mathrm{N}-21^{0} \mathrm{E}$ & Clgla, Apfla, Apagr & 7 & 0.36 & Andrzejewski (1963) \\
\hline$m$ & $50^{\circ} \mathrm{N}-30^{\circ} \mathrm{E}$ & Apagr & 7 & 0.32 & Sviridenko (1972) \\
\hline \multicolumn{4}{|c|}{ Mean (SD) } & \multicolumn{2}{|c|}{$0.312(0.050)$} \\
\hline
\end{tabular}


Appendix II - concluded.

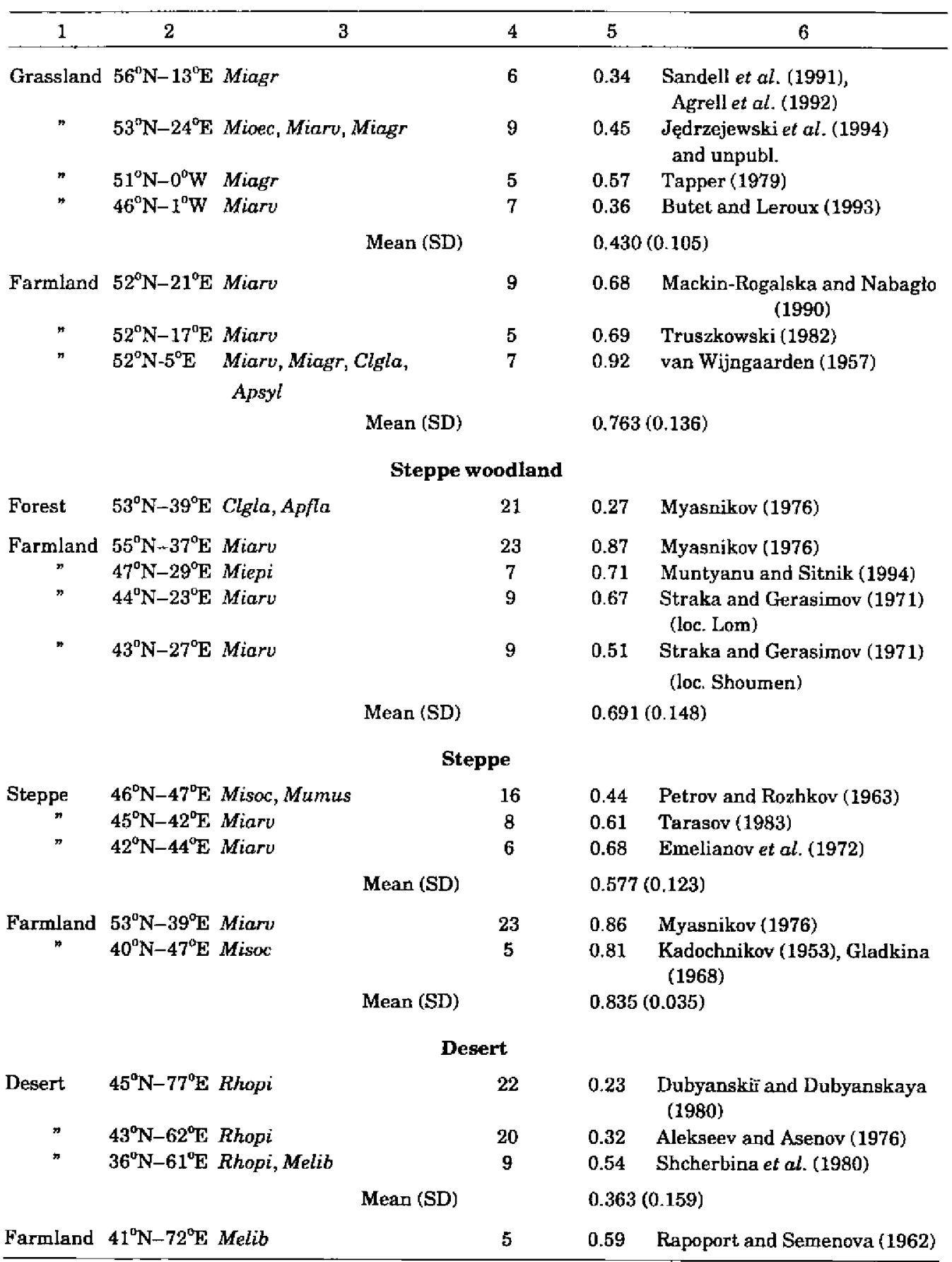


Appendix III. Data on estimates of densities (number per hectare) of rodents from the trapping studies that sampled the entire community of rodents (or one heavily dominating species) in spring and autumn seasons. Mean densities (in each study and in habitats within biomes) were calculated from all available spring and autumn data points. Biomes and habitat types as in Appendix I. Abbreviations of rodent Latin names as in Appendix II.

\begin{tabular}{|c|c|c|c|c|c|c|c|c|}
\hline \multirow{2}{*}{$\begin{array}{l}\text { Biome/ } \\
\text { habitat }\end{array}$} & \multirow{2}{*}{$\begin{array}{l}\text { Coordi- } \\
\text { nates }\end{array}$} & \multirow{2}{*}{ Species of rodents } & \multirow{2}{*}{$\begin{array}{c}\mathbf{N} \\
\text { sea- } \\
\text { sons }\end{array}$} & \multicolumn{4}{|c|}{ Densities (N/ha) } & \multirow{2}{*}{ Source } \\
\hline & & & & $\min$ & $\max$ & & SD) & \\
\hline 1 & 2 & 3 & 4 & 5 & 6 & & 7 & 8 \\
\hline \multicolumn{9}{|c|}{ Tundra } \\
\hline Tundra & $\begin{array}{l}69^{\circ} \mathrm{N}-21^{\circ} \mathrm{E} \\
61^{\circ} \mathrm{N}-8^{\circ} \mathrm{E}\end{array}$ & $\begin{array}{l}\text { Clrut, Clruf, Miagr } \\
\text { Lelem, Mioec, Clruf }\end{array}$ & $\begin{array}{r}7 \\
16\end{array}$ & $\begin{array}{l}0.6 \\
0.1\end{array}$ & $\begin{array}{r}110 \\
78\end{array}$ & $\begin{array}{l}38.4 \\
15.4\end{array}$ & $\begin{array}{l}(40.4) \\
(23.3)\end{array}$ & $\begin{array}{l}\text { Viitala }(1987) \\
\text { Lien et al. (1975) }\end{array}$ \\
\hline Mean (SD) & for a total sa & mple & 23 & 0.1 & 110 & 22.4 & $(30.6)$ & \\
\hline \multicolumn{9}{|c|}{ Boreal forests (taiga) } \\
\hline Forest & $68^{\circ} \mathrm{N}-24^{\circ} \mathrm{E}$ & $\begin{array}{l}\text { Clgla, Clrut, Clruf, } \\
\text { Miagr, Lelem }\end{array}$ & 8 & 0.7 & 39 & 15.0 & $(13.2)$ & Henttonen et al. (1987) \\
\hline$n$ & $63^{0} \mathrm{~N}-23^{0} \mathrm{E}$ & Clgla, Miagr, Miepi & 22 & 0 & 17 & 5.1 & $(5.2)$ & $\begin{array}{l}\text { Korpimäki and } \\
\text { Norrdahl (1991a,b) }\end{array}$ \\
\hline Mean (SD) & for a total sa & imple & 30 & 0 & 39 & 7.7 & $(9.0)$ & \\
\hline Farmland & $63^{\circ} \mathrm{N}-23^{\circ} \mathrm{E}$ & Miagr, Miepi, Clgla & 22 & 0.6 & 53 & 15.6 & $(13.2)$ & $\begin{array}{l}\text { Korpimäki and } \\
\text { Norrdahl }(1991 \mathrm{a}, \mathrm{b})\end{array}$ \\
\hline \multicolumn{9}{|c|}{ Temperate mixed forests } \\
\hline Forest & $56^{0} \mathrm{~N}-37^{\circ} \mathrm{E}$ & $C l g l a$, Apfla & 6 & 7 & 52 & 23.5 & $(16.7)$ & Smirin (1964) \\
\hline 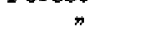 & $56^{\circ} \mathrm{N}-13^{\circ} \mathrm{E}$ & Miagr, Clgla, Apsyl & 5 & 12 & 95 & 48.2 & $(33.7)$ & Hansson (1971a) \\
\hline$n$ & $52^{0} \mathrm{~N}-17^{0} \mathrm{E}$ & Clgla, Apfla & 7 & 2 & 43 & 19.0 & $(14.5)$ & Goszczyński (1977) \\
\hline Mean (SD) & for a total sa & mple & 18 & 2 & 95 & 28.6 & $(24.2)$ & \\
\hline Grassland & $60^{\circ} \mathrm{N}-24^{\circ} \mathrm{E}$ & Miagr & 10 & 0 & 330 & 88.5( & $(109.8)$ & Myllymaki (1977) \\
\hline Farmland & $55^{\circ} \mathrm{N}-38^{\circ} \mathrm{E}$ & Miarv & 9 & 2 & 83 & 17.8 & $(27.5)$ & Karaseva (1960) \\
\hline \multicolumn{9}{|c|}{ Temperate deciduous forests } \\
\hline Forest & $57^{\circ} \mathrm{N}-10^{\circ} \mathrm{E}$ & Clgla, Apfla & 18 & 4 & 78 & 22.4 & $(20.2)$ & Jensen (1982) \\
\hline$n$ & $53^{\circ} \mathrm{N}-24^{\circ} \mathrm{E}$ & Clgla, Apfla & 15 & 5 & 269 & 43.3 & $(66.4)$ & $\begin{array}{l}\text { Jędrzejewski and } \\
\text { Jędrzejewska (1993), } \\
\text { Jędrzejewski et al. } \\
\text { (1992) and unpubl. }\end{array}$ \\
\hline$m$ & $52^{\circ} \mathrm{N}-21^{\circ} \mathrm{E}$ & Clgla, Apfla, Apagr & 13 & 2 & 31 & 10.5 & $(8.9)$ & Andrzejewski (1963) \\
\hline \multicolumn{3}{|c|}{ Mean (SD) for a total sample } & 46 & 2 & 269 & 25.9 & $(41.5)$ & \\
\hline Grassland & $56^{\circ} \mathrm{N}-13^{\circ} \mathrm{E}$ & Miagr & 11 & 24 & 331 & 98.0 & $(90.6)$ & $\begin{array}{c}\text { Sandell et al. (1991), } \\
\text { Agrell et al. (1992) }\end{array}$ \\
\hline$"$ & $53^{\circ} \mathrm{N}-23^{\circ} \mathrm{E}$ & Mioec & 4 & 146 & 756 & 405.00 & $(256.2)$ & Buchalczyk et al. (1970) \\
\hline$n$ & $51^{\circ} \mathrm{N}-0^{0} \mathrm{~W}$ & Miagr & 10 & 0.5 & 483 & 190.4( & $(169.3)$ & Tapper (1979) \\
\hline$"$ & $46^{\circ} \mathrm{N}-1^{\circ} \mathrm{W}$ & Miarv & 14 & 2 & 328 & 72.7 & $(87.2)$ & $\begin{array}{l}\text { Butet and Leroux } \\
\text { (1993) }\end{array}$ \\
\hline \multicolumn{3}{|c|}{ Mean (SD) for a total sample } & 39 & 0.5 & 756 & 144.11 & $(164.2)$ & \\
\hline
\end{tabular}


Appendix III - concluded.

\begin{tabular}{|c|c|c|c|c|c|c|c|}
\hline 1 & 2 & 3 & 4 & 5 & 6 & 7 & 8 \\
\hline $\begin{array}{c}\text { Farmland } \\
n\end{array}$ & $\begin{array}{l}52^{\mathrm{O}} \mathrm{N}-21^{\circ} \mathrm{E} \\
52^{\circ} \mathrm{N}-17^{\circ} \mathrm{E}\end{array}$ & $\begin{array}{l}\text { Miarv } \\
\text { Miarv }\end{array}$ & $\begin{array}{r}3 \\
10\end{array}$ & $\begin{array}{r}121 \\
4\end{array}$ & $\begin{array}{r}753 \\
1450\end{array}$ & $\begin{array}{l}462.7(319.1) \\
261.8(440.0)\end{array}$ & $\begin{array}{l}\text { Liro (1974) } \\
\text { Truszkowski (1982) }\end{array}$ \\
\hline \multicolumn{3}{|c|}{ Mean (SD) for a total sample } & 13 & 4 & 1450 & $308.2(412.2)$ & \\
\hline \multicolumn{8}{|c|}{ Steppe woodland } \\
\hline Farmland & $47^{\circ} \mathrm{N}-29^{\circ} \mathrm{E}$ & Miepi & 14 & 6 & 761 & $143.2(236.9)$ & $\begin{array}{l}\text { Muntyanu and } \\
\text { Sitnik (1994) }\end{array}$ \\
\hline \multicolumn{8}{|c|}{ Steppe } \\
\hline Steppe & $48^{\circ} \mathrm{N}-114^{\circ} \mathrm{F}$ & Mibra & 8 & 1 & 786 & $225.6(324.6)$ & $\begin{array}{l}\text { Kucheruk and } \\
\text { Dunaeva (1948) }\end{array}$ \\
\hline$"$ & $47^{\circ} \mathrm{N}-108^{\circ} \mathrm{E}$ & Mibra & 2 & 22 & 109 & $65.5 \quad(61.5)$ & Weiner et al. (1982b) \\
\hline$n$ & $46^{\circ} \mathrm{N}-47^{\circ} \mathrm{E}$ & Misoc, Mumus & 10 & 2 & 108 & $19.1 \quad(32.7)$ & $\begin{array}{l}\text { Petrov and } \\
\text { Rozhkov (1963) }\end{array}$ \\
\hline$n$ & $45^{\circ} \mathrm{N}-39^{\circ} \mathrm{E}$ & $\begin{array}{l}\text { Miarv, Pimaj, } \\
\text { Apagr, Apsyl, } \\
\text { Mumus }\end{array}$ & 4 & 63 & 209 & $146.0 \quad(60.9)$ & $\begin{array}{l}\text { Lavrova and } \\
\text { Lebedeva (1962) }\end{array}$ \\
\hline$"$ & $40^{\circ} \mathrm{N}-47^{\circ} \mathrm{E}$ & Misoc & 3 & 110 & $\mathbf{5 5 0}$ & $260.0(251.2)$ & Gladkina (1968) \\
\hline Mean (SD) & for a total sa & ample & 27 & 1 & 786 & $129.3(209.8)$ & \\
\hline Farmland & $40^{\circ} \mathrm{N}-47^{0} \mathrm{E}$ & Misoc & 10 & 0.5 & 1800 & $490.4(724.0)$ & $\begin{array}{l}\text { Kadochnikov (1953), } \\
\text { Gladkina (1968) }\end{array}$ \\
\hline \multicolumn{8}{|c|}{ Desert } \\
\hline$\underset{n}{\text { Desert }}$ & $\begin{array}{l}47^{\circ} \mathrm{N}-49^{\circ} \mathrm{E} \\
45^{\circ} \mathrm{N}-77^{\circ} \mathrm{E}\end{array}$ & $\begin{array}{l}\text { Memer, Metam } \\
\text { Rhopi }\end{array}$ & $\begin{array}{l}10 \\
22\end{array}$ & $\begin{array}{l}4 \\
2\end{array}$ & $\begin{array}{l}42 \\
15\end{array}$ & $\begin{array}{rr}13.5 & (11.2) \\
7.2 & (3.5)\end{array}$ & $\begin{array}{l}\text { Tropin (1963) } \\
\text { Dubyanskiï and } \\
\text { Dubyanskaya (1980) }\end{array}$ \\
\hline Mean (SD) & for a total sa & ample & 32 & 2 & 42 & $(7.3)$ & \\
\hline Farmland & $41^{\circ} \mathrm{N}-72^{\circ} \mathrm{E}$ & Melib & 10 & 1 & 50 & $13.8 \quad(16.9)$ & $\begin{array}{l}\text { Rapoport and } \\
\text { Semenova (1962) }\end{array}$ \\
\hline
\end{tabular}

